\title{
Nutritional Value and Preventive Role of Nigella sativa L. and Its Main Component Thymoquinone in Cancer: An Evidenced-Based Review of Preclinical and Clinical Studies
}

\author{
Johura Ansary ${ }^{1,+}+(\mathbb{D})$, Francesca Giampieri ${ }^{1,2,+(\mathbb{D})}$, Tamara Y. Forbes-Hernandez ${ }^{3}$, Lucia Regolo ${ }^{1}$ (D), Denise Quinzi ${ }^{1}$,

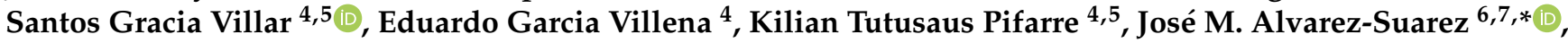 \\ Maurizio Battino 1,8,*(D) and Danila Cianciosi ${ }^{1, *(D)}$
}

1 Department of Clinical Sciences, Polytechnic University of Marche, 60131 Ancona, Italy; nubansary@gmail.com (J.A.); f.giampieri@univpm.it (F.G.); luciaregolo@gmail.com (L.R.); denise81quinzi@gmail.com (D.Q.)

2 Department of Biochemistry, Faculty of Sciences, King Abdulaziz University, Jeddah 21589, Saudi Arabia

3 Nutrition and Food Science Group, Department of Analytical and Food Chemistry, CITACA, CACTI, University of Vigo, 36310 Vigo, Spain; tforbes@uvigo.es

check for

updates

Citation: Ansary, J.; Giampieri, F.; Forbes-Hernandez, T.Y.; Regolo, L.; Quinzi, D.; Gracia Villar, S.; Garcia Villena, E.; Tutusaus Pifarre, K.; Alvarez-Suarez, J.M.; Battino, M.; et al. Nutritional Value and Preventive Role of Nigella sativa L. and Its Main Component Thymoquinone in

Cancer: An Evidenced-Based Review of Preclinical and Clinical Studies. Molecules 2021, 26, 2108. https:// doi.org/10.3390/molecules26082108

Academic Editors: Maria José Rodríguez-Lagunas and Malen Massot-Cladera

Received: 26 February 2021

Accepted: 3 April 2021

Published: 7 April 2021

Publisher's Note: MDPI stays neutral with regard to jurisdictional claims in published maps and institutional affiliations.

Copyright: (C) 2021 by the authors. Licensee MDPI, Basel, Switzerland. This article is an open access article distributed under the terms and conditions of the Creative Commons Attribution (CC BY) license (https:// creativecommons.org/licenses/by/ $4.0 /)$.
4 Research Center for Foods, Nutritional Biochemistry and Health, Universidad Europea del Atlántico, Isabel Torres 21, 39011 Santander, Spain; santos.gracia@uneatlantico.es (S.G.V.); eduardo.garcia@uneatlantico.es (E.G.V.); kilian.tutusaus@uneatlantico.es (K.T.P.)

5 Research Center for Foods, Nutritional Biochemistry and Health, Universidad Internacional Iberoamericana, Campeche 24560, Mexico

6 Departamento de Ingeniería en Alimentos, Colegio de Ciencias e Ingenierías, Universidad San Francisco de Quito, Quito 170157, Ecuador

7 King Fahd Medical Research Center, King Abdulaziz University, Jeddah 21589, Saudi Arabia

8 International Research Center for Food Nutrition and Safety, Jiangsu University, Zhenjiang 212013, China

* Correspondence: jalvarez@usfq.edu.ec (J.M.A.-S.); m.a.battino@univpm.it (M.B.);

d.cianciosi@pm.univpm.it (D.C.); Tel.: +593-2-297-1700 (J.M.A.-S.); +339-071-220-4646 (M.B.); +339-071-220-4136 (D.C.)

$+\quad$ These authors contributed equally to this work.

Abstract: In recent times, scientific attention has been paid to different foods and their bioactive components for the ability to inhibit the onset and progress of different types of cancer. Nigella sativa extract, powder and seed oil and its main components, thymoquinone and $\alpha$-hederin, have showed potent anticancer and chemosensitizing effects against various types of cancer, such as liver, colon, breast, renal, cervical, lung, ovarian, pancreatic, prostate and skin tumors, through the modulation of various molecular signaling pathways. Herein, the purpose of this review was to highlight the anticancer activity of Nigella sativa and it constitutes, focusing on different in vitro, in vivo and clinical studies and projects, in order to underline their antiproliferative, proapoptotic, cytotoxic and antimetastatic effects. Particular attention has been also given to the synergistic effect of Nigella sativa and it constitutes with chemotherapeutic drugs, and to the synthesized analogs of thymoquinone that seem to enhance the chemo-sensitizing potential. This review could be a useful step towards new research on N. sativa and cancer, to include this plant in the dietary treatments in support to conventional therapies, for the best achievement of therapeutic goals.

Keywords: Nigella sativa; nutritional composition; anticancer properties; molecular pathways; combined therapy

\section{Introduction}

Cancer is one of the major threats of modern life, being the second cause of death after myocardial infarction worldwide [1,2]. The mechanisms underlying cancer development and progression vary widely among cancer types and unfortunately are not well understood. However, mutations in genetic or epigenetic pathways, including tumor suppressor 
genes and oncogenes, have been reported in a great number of cancer cases [3]. In recent years, manifold strategies have been developed to inhibit cancer progression, including hormonal therapy, surgery, radiation and chemotherapy. Chemotherapy is one of the main approaches to treat cancer, but unfortunately in various types of cancer it has showed limited potential in long-term treatment, due to toxic effects, drug resistance and the ability of cancer cells to alter different signaling pathways to escape from death [4,5]. Indeed, tumor cells execute various approach to block the efficacy of drugs, such as the increase of drug efflux, the modification of drug metabolism, the activation of cell survival pathway, the inhibition of apoptosis and the mutation of drug targets [4,6]. In addition, the drug resistance has increased for the presence of cancer stem cells (CSCs), which have brought harmful effects against cancer treatment [7]. Besides, cancer diagnosis and management and available cytotoxic drugs are not easily affordable or available in certain places, especially in developing countries. For these reasons, a large proportion of the population prefers to patronize complementary and alternative medicine [8]. In this scenario, it is important to identify novel compounds that are non-toxic and can be used as combined therapy to improve the response of cancer cells to chemotherapeutic mediators.

Natural compounds are non-nutritive secondary plant compounds with health-promoting and disease preventive properties, mainly found in fruits, vegetables, grain, herbs, spice and other plant foods. Among them, the use of herbals in medicine is widespread and is growing dramatically because of their nourishing and synergistic actions that make them an excellent treatment choice. Among others, Nigella sativa (N. sativa) can be a valid tool for health promotion, due to its low toxicity and multiple mechanisms of action [5]. For example, recent reports suggest that the oil and extracts of $N$. sativa have antimicrobial and anti-inflammatory activity, immune stimulant properties, together with anticancer, antioxidant, hypoglycemic, spasmolytic and bronchodilator capacities [2,5,9-15]. Similarly, thymoquinone (TQ), the prominent compound of N. sativa, has shown to exert antiproliferative effects on different cancer cell lines, such as ovarian, colon, larynx, breast, leukemia, lung and osteosarcoma [11].

Recently, increased attention and intensive research efforts have been also devoted toward understanding the molecular mechanisms involved in the potent anticancer activities of N. sativa and its main compounds (Figure 1).

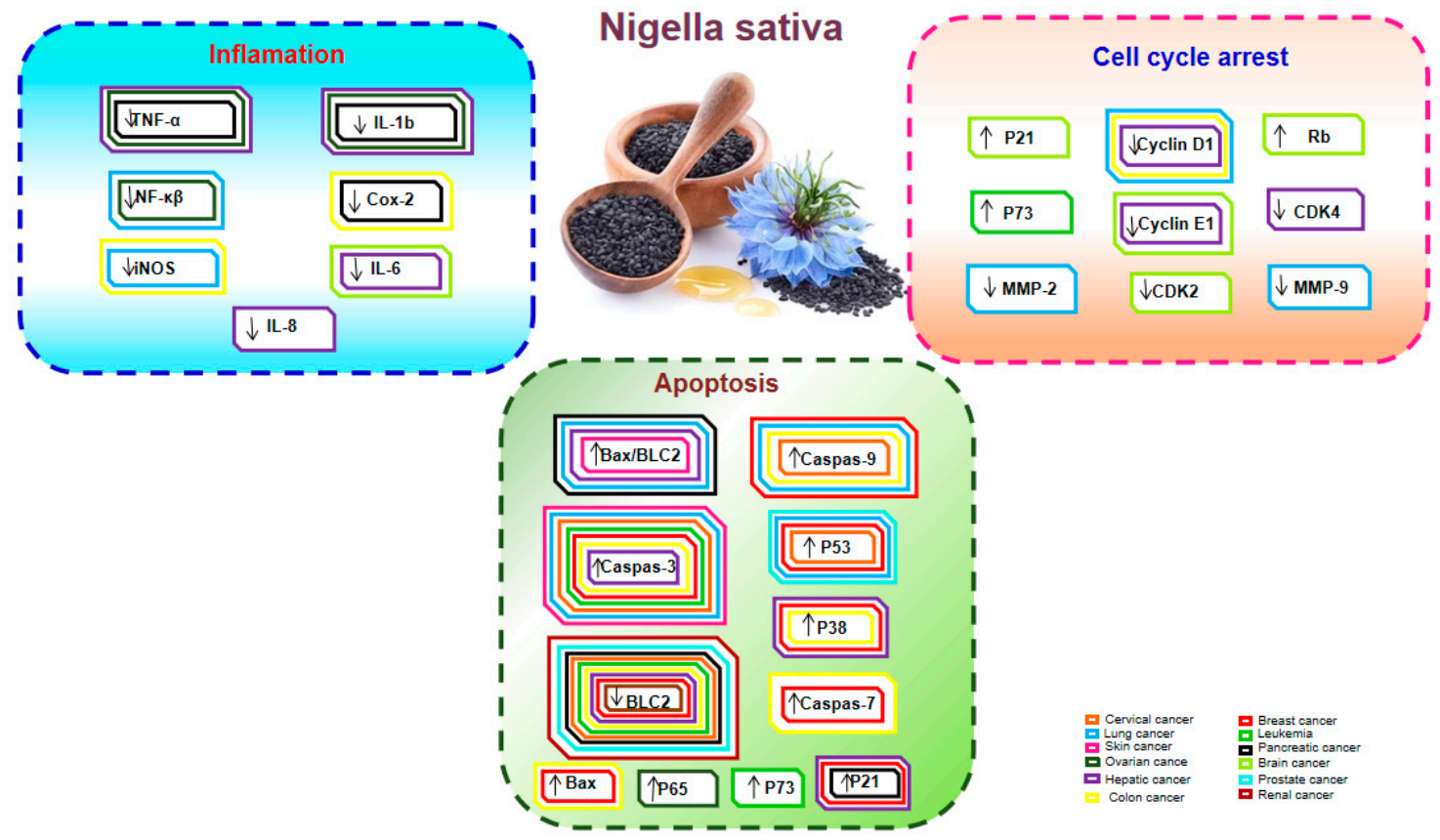

Figure 1. A brief overview of several cellular signaling pathways influenced by N. sativa and its main components through molecular targets in various types of cancer. 
The aim of this review is to summarize the proximal, nutritional and phytochemical composition of $N$. sativa, the anticancer effect of whole extracts, its constituents and their analogs on different type of cancer together with the combined therapy with different anticancer drugs.

\section{Literature Search}

The literature search was conducted using various scientific databases, including Medline, Scopus, Google Scholar and Web of Science, by using keywords such as "black seed", "N. sativa" and "active compounds", "N. sativa and nutritional composition", "N. sativa and fatty acid profile", "N. sativa and analog", "N. sativa" or "Thymoquinone" and "breast cancer", "hepatic cancer", "colon cancer", "renal cancer", "cervical cancer", "leukemia", "lung cancer", "ovarian cancer", "pancreatic cancer", "prostate cancer", "skin cancer", etc., "black cumin", or "N. sativa" and "combine therapy" and related clinical trials. All the articles included were published from 2000 to 2020 in English.

\section{N. sativa and Its Major Constituents}

N. sativa is an annual herb belonging to the family of Ranunculaceae. Its seeds and oil have been commonly used as a traditional remedy for a variety of health issues for more than 2000 years. Greenish, H.G., reported for the first time the chemical composition of $N$. sativa seeds in 1880, highlighting the presence of fibers, carbohydrates, proteins, oils, ashes, moisturizers, etc., as shown in Table 1 [12-30].

Table 1. Chemical and nutritional composition of Nigella sativa.

\begin{tabular}{cc}
\hline Proximate Analysis & $\mathbf{( \% )}$ \\
\hline Moisture & $3.8-7.0$ \\
Crude protein & $18.59-31.2$ \\
Crude fat & $22.0-56.4$ \\
Total ash & $4.0-4.29$ \\
Crude fiber & $3.7-4.7$ \\
Carbohydrates & $24.9-40.0$ \\
\hline Fat Soluble Vitamin & $\mathbf{m g} / \mathbf{K g}$ \\
\hline DL- $\alpha$-tocopherol & 0.177 \\
DL-tocopherol & 9.027 \\
DL- $\gamma$-tocopherol & 5.427 \\
All trans retinol & 0.277 \\
\hline Water Soluble Vitamin & $\mathbf{m g} / \mathbf{K g}$ \\
\hline B1 & $13-18$ \\
B6 & $4-15$ \\
Niacin & $33-97$ \\
Folic acid & $400-870$ \\
\hline Minerals & $\mathbf{m g} / \mathbf{1 0 0} \mathbf{g}$ \\
\hline Iron & $9.10-15.40$ \\
Copper & $1.50-3.75$ \\
Sodium & $41.20-55.0$ \\
Potassium & $442.3-675.0$ \\
Calcium & $154.4-305.0$ \\
Zinc & $3.36-6.60$ \\
Phosphorus & $378.12-576.90$ \\
Magnesium & $134.90-147.05$ \\
\hline
\end{tabular}

Diverse active compounds have been isolated and identified in different $N$. sativa varieties: beyond TQ, the main components are dithymoquinone, thymohydroquinone and thymol, $\mathrm{p}$-cymene nigeglanine, nigellicine, nigellidine, nigellimine, $\mathrm{t}$-anethol and 4-terpineol (Figure 2), together with carbohydrates, vitamins, mineral elements, proteins 
and essential amino acids [12-30].

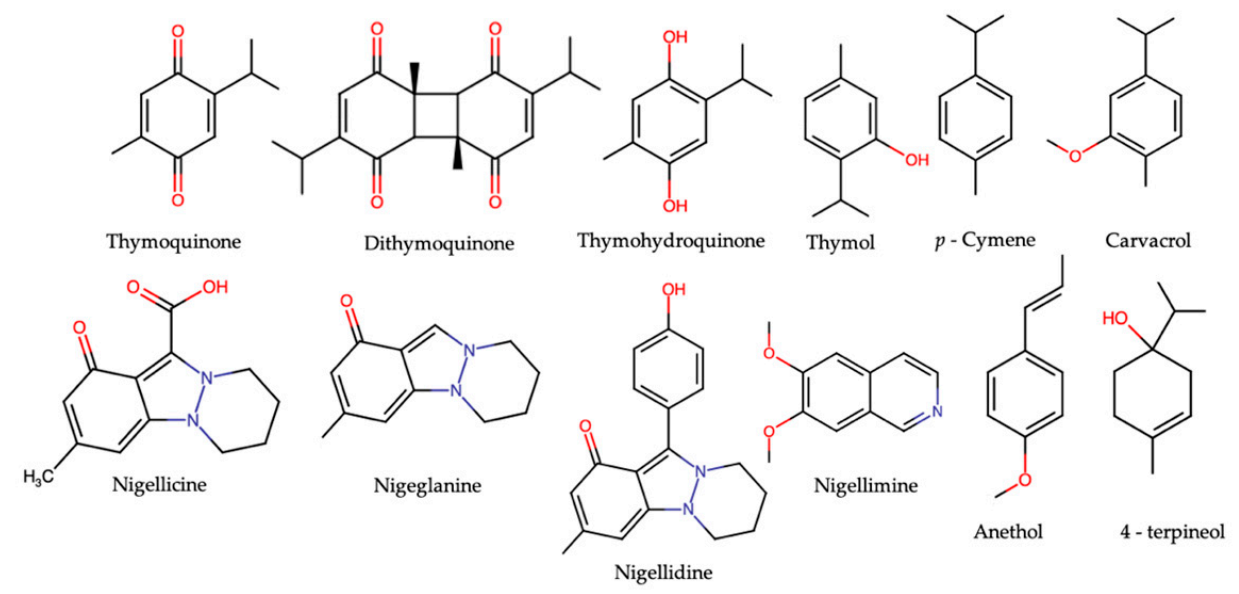

Figure 2. Some main components of N. sativa.

N. sativa is also a very good source of fatty acids (Table 2), being the linoleic and oleic acids the most representative ones [14-33].

Table 2. Fatty acid profile of N. sativa.

\begin{tabular}{ccc}
\hline Fatty Acid Profiles & Molecular Formula & $\%$ \\
\hline Myristic acid & $\mathrm{CH}_{3}\left(\mathrm{CH}_{2}\right)_{12} \mathrm{COOH}$ & $0.29-1.1$ \\
Myristoleic acid & $\mathrm{C}_{14} \mathrm{H}_{26} \mathrm{O}_{2}$ & $2.42-2.65$ \\
Palimitic acid & $\mathrm{C}_{16} \mathrm{H}_{32} \mathrm{O}_{2}$ & $9.9-18.4$ \\
Stearic acid & $\mathrm{C}_{18} \mathrm{H}_{36} \mathrm{O}_{2}$ & $1.51-3.70$ \\
Oleic acid & $\mathrm{C}_{18} \mathrm{H}_{34} \mathrm{O}_{2}$ & $18.9-25.69$ \\
Linoleic acid & $\mathrm{C}_{18} \mathrm{H}_{32} \mathrm{O}_{2}$ & $47.0-67.5$ \\
Linolenic acid & $\mathrm{C}_{18} \mathrm{H}_{30} \mathrm{O}_{2}$ & $0.19-2.70$ \\
Arachidic acid & $\mathrm{C}_{20} \mathrm{H}_{40} \mathrm{O}_{2}$ & $0.19-0.25$ \\
Eicosenoic acid & $\mathrm{C}_{20} \mathrm{H}_{38} \mathrm{O}_{2}$ & $0.32-1.0$ \\
Arachidonic acid & $\mathrm{C}_{20} \mathrm{H}_{32} \mathrm{O}_{2}$ & $0.19-0.25$ \\
Behenic acid & $\mathrm{C}_{22} \mathrm{H}_{44} \mathrm{O}_{2}$ & $1.80-2.60$ \\
Saturated fatty acids & n.a & $16.25-26.7$ \\
Monounsaturated fatty acids & n.a. & $19.22-29.11$ \\
Poly unsaturated fatty acids & n.a. & $49.1-72.42$ \\
\hline
\end{tabular}

\section{N. sativa as an Anticancer Agent}

$N$. sativa exerts significant antiproliferative effects against various types of cancer, such as liver, colon, breast, cervical, lung, pancreatic, prostate cancer, etc. (Figure 3).

Several in vitro and in vivo research have revealed that its anticancer activity is mediated through the modulation of different biological processes and pathways, such as proliferation, cell cycle, apoptosis, angiogenesis, carcinogenesis and metastasis.

\subsection{Breast Cancer}

About 1.7 million women have been diagnosed with breast cancer in 2012 and over 508,000 women died due to this disease in 2011. In clinical practice, many options are available for breast cancer treatment, such as radiation, surgery, hormonal, chemotherapy and targeted therapy [34]. For example, N. sativa seed proteins and TQ showed antiproliferative effects, by promoting apoptosis through p38 phosphorylation, ROS production and by activating caspases, p53, p21 and Bax and decreasing Bcl-2 in human adeno- and ductal carcinoma cells, including MCF-7, 47D and MDA-MB-468 cells [35-37]. Furthermore, in human adenocarcinoma MDA-MB-231 triple negative cells, TQ inhibited the overexpression of chemokine receptor type 4 (CXCR4), by downregulating NF-k $\beta$, decreased cell invasion and migration, reduced the expression of Bcl-2, Bcl-xL and survivin and activated 
the peroxisome proliferator-activated receptors (PPAR)- $\gamma$ pathway $[38,39]$. Similarly, TQ inhibited tumor growth by downregulating the expression of N-Cadherin and upregulating the expression E-cadherin gene, decreasing metastatic process in mouse breast cancer cell line $4 \mathrm{~T} 1$ [40].

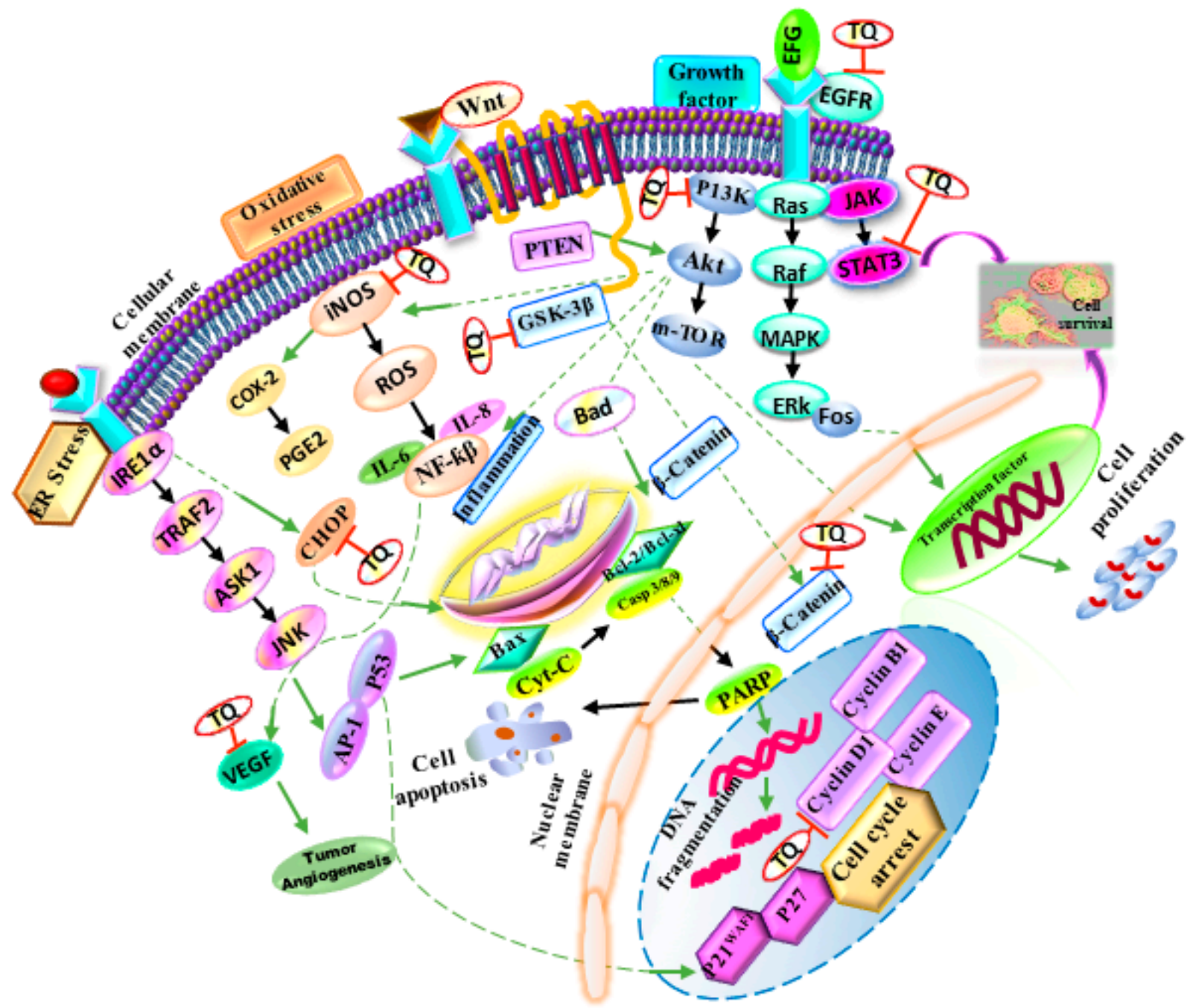

Figure 3. Schematic representation of the anticancer mechanisms of $N$. sativa and its main components. Thymoquinone (TQ) is able to inhibit cancer development and to regulate various genes involved in survival, proliferation, invasion, angiogenesis, metastasis and apoptosis.

Moreover, TQ was effective in damaging mitochondrial membrane integrity, by promoting the release of cytochrome $\mathrm{c}$ and the induction of apoptosis, arresting the cell cycle at G1 phase and concomitantly suppressing the growth of p53-deficient breast carcinoma MDA-MB-231 and MDA-MB-468 cells without affecting normal mammary epithelial cells [41]. Furthermore, in human adenocarcinoma MCF-7 cells, TQ induced apoptosis, by disrupting mitochondrial membrane potential and activating caspases and PARP cleavage and increasing Bax/Bcl2 ratio, arrested cell cycle at G2/M and sub-G1 phase via the modulation of the Akt/PTEN axis [42].

Regarding in vivo models, in mouse injected with MDA-MB-231 cells, TQ treatment significantly suppressed multiple lung, brain and bone metastases in a dose-dependent manner, reducing the osteolytic lesions and the expression of metastatic biomarkers [39], while in Sprague-Dawley rats injected with 7,12-Dimethylbenzathracene (DMBA) the emulsion of $N$. sativa oil fraction exhibited antiproliferative effects, by reducing the level of detrimental oxidative stress, destroying endocrine derangement and increasing apoptosis [43]. 


\subsection{Colon Cancer}

Colorectal cancer (CRC) is the second most common cancer in Europe and its onset is strictly correlated with several risk factors, such as high-fat diet poor in fiber, high alcohol consumption, red meat, obesity, smoking, lack of physical exercise, diabetes, older age and several genetic and epigenetic alterations. Protective effects have been found for N. sativa and its compounds in CRC. For instance, $\alpha$-hederin and TQ, the two principal bioactive constituents of $N$. sativa, suppressed cellular viability in human colorectal adenocarcinoma HT-29 cells in a dose and time-dependent manner, by inducing apoptosis and necrosis [44]. TQ has demonstrated the efficacy also to promote autophagy and apoptosis in an irinotecan-resistant (CPT-11-R) LoVo colon cancer cells by inducing mitochondrial outer membrane permeabilization, activating JNK and p38 and inhibiting NF-k $\beta$, ERK1/2 and PI3K pathways $[45,46]$. In addition, it promoted ROS-dependent apoptosis in human colorectal carcinoma Caco-2, HCT-116, LoVo and HT-29 cells, by activating caspases $3 / 7$, JNK and ERKs, without showing cytotoxic effect to normal human intestinal FHs74Int cells [47]. Furthermore, high dose of TQ exerted antiproliferative effect in human colon adenocarcinoma LoVo cells through the downregulation of p-PI3K, p-Akt, p-GSK3 $\beta$ and $\beta$-catenin, and thereby of COX-2 and prostaglandin E2 (PGE2) [48]. Moreover, TQ mediated apoptosis in human colon adenocarcinoma HCT116 cells by increasing Bax, decreasing Bcl-2 and Bcl-xl expression and activating caspase-9, -7 and -3 and PARP cleavage, and inhibited STAT3 pathway and its downstream targets, including survivin, cyclin D1 and D2, through the suppression of JAK2- and Src-mediated phosphorylation of EGFR tyrosine kinase [49].

Regarding in vivo studies, in azoxymethane (AOM)-treated Sprague-Dawley rats, $N$. sativa and its main constituents (selenium, TQ and DL- $\alpha$-tocopherol) prevented oxidative DNA damage and inhibited malondialdehyde (MDA) liver contents [50], while in PGE2treated nude mice TQ inhibited the growth of metastatic LoVo cells by downregulating COX-2 and $\beta$-catenin levels in different tissues [48]; finally, in 1,2-dimethylhydrazine $(\mathrm{DMH})$-treated rats TQ showed antitumor effect by reducing cell proliferation, tumor volume, progression and invasion through the suppression of the colonic proliferating cell nuclear antigen (PCNA) expression and vascular endothelial growth factor (VEGF) production [51].

\subsection{Hepatic Cancer}

Hepatocellular carcinoma is the most common primary liver cancer and numerous strategies have been used for the treatment of this disease. N. sativa and TQ have strong antioxidant properties and have been found to exert chemopreventive effects in this kind of cancer. For example, in human hepatocellular carcinoma HepG2 cells alcoholic extracts of N. sativa decreased cell viability and increased apoptotic cell death through the improvement of the antioxidant condition [52]. Similarly, in HepG2, TQ arrested cell cycle at the G2/M phase and induced apoptosis, by increasing the ratio of Bax/BCL-2 through the activation of caspase- 3 and -9 and by suppressing the Bcl-2 expression and PARP cleavage; additionally, it inhibited the expression of NF- $\mathrm{k} \beta$, IL- 8 and its receptors, stimulated TRAIL death receptors and reduced $\mathrm{Bcl}-\mathrm{xS}$ gene expression [53,54]. TQ also showed a significant inhibitory effect on phase I CYP1A1 enzyme and increased the content of glutathione (GSH) and the activity of glutathione transferase (GST) in HepG2 cells [53]. Moreover, thymol, another bioactive compound of N. sativa, exerted cytotoxic effect in HepG2 cells and together with carvacrol, it protected liver cells via antioxidant activity and repression of proinflammatory cytokines, such as TNF- $\alpha$ and IL-1 $\beta$ [55].

Regarding in vivo studies, in diethylnitrosamine (DENA)-treated rats N. sativa and TQ suppressed the EGFR/ERK1/2 signaling pathway and augmented ERK and p38 phosphorylation by modulating PCNA, c-fos and Bcl-2, and protected liver from oxidative stress injury by enhancing the levels of antioxidant enzymes, and decreasing the concentrations of alkaline phosphatase, alanine trans aminase, total bilirubin and total NOx [56,57]. Inter- 
estingly, N. sativa ethanolic extract exerted antitumor effect via reducing the serum levels of alpha-fetoprotein, TNF- $\alpha$, IL-6 levels NO and iNOS activity in DENA-treated rats [58].

Finally, in N-Nitrosodiethylamine (NDEA) treated rats, TQ exerted antiproliferative activities and inhibited hepatic tumorigenesis by regulating cell cycle at the G1/S phase and modulating some specific proteins (i.e., p21(WAF1/CIP1, Cyclin D1), CDK4 and Cyclin E) [59].

\subsection{Lung Cancer}

The rate of mortality associated with lung cancer is high in the world. The natural source has recently received much attention for their chemotherapeutic effects against this type of cancer. In this context, in human lung carcinoma A549, NCI-H460 and NCI-H146 cells, TQ promoted apoptosis, by elevating Bax/Bcl-2 ratio, p53 and caspase 3 and 9, arrested cell cycle and suppressed cell viability, invasion and migration, by phosphorylating of ERK1/2 and suppressing cyclin D1, PCNA, MMP2 and MMP9 expression, and inhibited neoangiogenesis by decreasing proangiogenic cytokines ENA-78, Gro-alpha [60-62]. Interestingly, TQ had no antiproliferative effects on pulmonary fibroblast cell line MRC-5 [60]. TQ may act also as a new microtubule-targeting agent, by reducing cell viability, depolymerizing microtubules, inducing apoptosis and cell cycle arrest at the G2/M phase in A549 lung cancer cells without affecting the microtubule network of normal human umbilical vein endothelial (HUVEC) cells; it was also able to suppress tubulin polymerization in the cell-free system in a time-dependent manner and showed antimitotic effect through the bind to the tubulin in the microtubule network [63].

To the best of our knowledge, there is only one in vivo study on TQ in lung cancer: in monocrotaline (MCT) treated rats, the intake of TQ significantly increased cancer apoptosis and inhibited pulmonary arterial remodeling via p38MAPK/NF- $\kappa \beta$ signaling pathway [64].

\subsection{Pancreatic Cancer}

Pancreatic cancer is one of the main causes of death among male cancer in the world. TQ is a potential candidate for the development of novel therapies against this cancer. For example, in human adenocarcinoma FG/COLO357 and CD18/HPAF81 cells, TQ was able to promote apoptosis, decrease motility and migration by reducing MUC4 and Bcl-xL expression via the activation of c-Jun NH2-terminal kinase and p38 pathways [65], while in human pancreatic carcinoma HS766T cells TQ from N. sativa oil extract induced a antiproliferative effect, by upregulating p21 expression, suppressing histone deacetylase activity, decreasing MCP-1, TNF- $\alpha$, IL-1b and Cox-2 via NF-k $\beta$ modulation [66]. Additionally, in different human pancreatic cancer cells (MiaPaCa-2, BxPC-3, AsPC-1 and HPAC), TQ-4A1, TQ-5A1 and TQ-2G analogs showed more potent antiproliferative activity than parental TQ by reducing cell viability, stimulating apoptosis through the downregulation of Bcl-2, survivin and upregulation of Bax/Bcl-2 ratio and reducing COX-1 and COX-2 enzyme activity without any toxic effects on the normal cell $[67,68]$.

\subsection{Cervical Cancer}

N. sativa seed extracts and TQ have shown to exert antitumor activities against cervical cancer. For example, in human cervical adenocarcinoma HeLa cells the extract of different solvents (n-hexane, methanolic and chloroform) mediated apoptosis via increasing p53, caspase-3, -8 and -9 , and downregulating Bcl-2 and Bcl- $X_{L}$ expression [69], while TQ induced apoptosis by modulating 84 genes, including the proapoptotic ones, such as BIK, FASL, BCL2L10 and CASP1, and the antiapoptotic ones, such as NF- $k \beta$ and RELA [70]. Interestingly, in human cervical carcinoma SiHa cells TQ induced apoptosis, arrested cell cycle at the sub-G1 phase, by modulating p53 and Bcl2 expression, decreased proliferation, reduced GSH levels and increased MDA concentration, without cytotoxic effect on normal cells (3T3-L1 and Vero cells) [71,72], while in human cervical carcinoma C33A cells TQ promoted apoptosis by activating caspase 3 [73]. Furthermore, TQ exerted cytotoxic effects, 
inhibited the migration and invasion processes and induced apoptosis in a time and dosedependent manner in human cervical carcinoma CaSki cells, where it acted on Twist 1 and Zeb1 and promoted E-cadherin expression [74]. Recently, the effect of TQ derivatives has been evaluated as anticancer drugs in cervical tumor. For example, Poloxin, a synthetic TQ derivative, was able to suppress serine/threonine kinase Polo-like kinase 1 (Plk1) and inhibit its functions in vitro, promoting Plk1 mislocalization, chromosome congression defects, mitotic arrest and apoptosis in HeLa cells [75].

\subsection{Leukemia and Blood Cancer}

N. sativa and TQ exert anticancer activities also on blood tumors. For example, in immortalized line of human T lymphocytes (Jurkat cells), and in an acute lymphocyte leukemic cell line (CEMss cells) TQ played proapoptotic activity via downregulation of ubiquitin-like, containing PHD and RING finger domains, 1 (UHRF1) and cyclic nucleotide phosphodiesterase (PDE)1A, arrested cell cycle by targeting p73-dependent pathway and stimulated caspases 3 and 8, Bax, DNA fragmentation, ROS generation and reduced Bcl-2 through mitochondrial-induced apoptosis [76,77]. Similarly, in Jurkat cells, N. sativa seed oil has shown anticancer activities by degrading $\alpha / \beta$ tubulin with the upregulation of the tumor suppressor p73 and by inducing apoptosis, but had no effect on $\alpha / \beta$ tubulin protein expression in normal human fibroblast cells [78]. Moreover, in different human leukemia cells, including Kasumi-1, MV4-11, THP-1 and ML-1 cells, TQ inhibited DNA (cytosine-5)-methyltransferase 1 (DNMT1) methylation activity via breakdown of the Sp1/NF-kB complex from the DNMT1 promoter, reduced colony formation and promoted cell apoptosis through activation of caspases [79]. TQ modulated also morphological patterns of apoptosis, by promoting cytoplasmic shrinkage, membrane blebbing and DNA fragmentation on murine leukemia WEHI-3 cells, thus inducing cytotoxicity [80].

A recent study also suggested that $T Q$ could be used as an epigenetic drug that induces both histone post-translational modifications and DNA methylation regulating several tumor suppressor genes (TSGs) with subsequent apoptosis. Specifically, in Jurkat cells TQ suppressed cell growth, by upregulating some TSGs, that are usually suppressed in cancer, such as DLC1, PPAR, ST7, FOXO6, TET2, CYP1B1, SALL4 and DDIT3 along with activating several proapoptotic genes, such as RASL11B, RASD1, GNG3, BAD and BIK [81]. Moreover, in IL-6-dependent human MDN, XG-2 cell lines, TQ showed chemopreventive and chemotherapeutic effects through the inhibition of CXCL12 mediated chemotaxis and the downregulation of CXCR4 expression and increased CD95 levels and susceptibility to Fas-mediated apoptosis in primary cells isolated from multiple myeloma patients without inducing any apoptotic effect on peripheral blood mononuclear cells from healthy donors [82].

In addition, TQ derivatives, bound to terpene residues, showed more potent antiproliferative effect than the native compound through the induction of apoptosis associated with DNA laddering, the reduction of mitochondrial membrane potential and the raise in ROS in human HL-60 leukemia cells [83]. Similar effects have been obtained in in vivo studies, where TQ decreased splenomegaly and suppressed leukemia cell growth in lungs and livers after i.v. administration of TQ in leukemia-bearing mice [79], and in BALB/c mice where it reduced spleen and liver weight and suppressed WEHI-3 growth, showing interesting antileukemic activity [80].

\subsection{Kidney and Bladder Cancer}

Recent studies suggested that TQ is a potential anticancer agent in renal cancer, exerting an antiproliferative effect by (i) reducing angiogenesis, (ii) preventing interaction between HSP90 and HIF- $1 \alpha$, (iii) degrading HIF- $1 \alpha$ protein, (iv) changing glucose, lactate, and ATP levels as a result of anaerobic metabolic disturbance, (v) decreasing mitochondrial membrane potential and consequent cytochrome $\mathrm{c}$ release into cytoplasm, (vi) arresting cell cycle at sub-G1, (vii) inducing ROS mediated apoptosis through the modulation of the expression of antiapoptotic proteins such as Bcl-2 and c-FLIP, or and pro- 
oncogenic JAK2/STAT3 pathway and (viii) preventing migration, invasion and epithelialmesenchymal transition (EMT) via autophagy-dependent AMPK/mTOR signaling pathway, in several human renal carcinoma cells, such as Caki-1, Caki-2, A498, 786-O and ACHN cells [84-86]. Additionally, in human renal adenocarcinoma 769-P and 786-O cells, TQ increased the level of E-cadherin and decreased those of ZEB1, Snail and vimentin, by increasing the expression of LKB and AMPK: these results highlighted that TQ markedly reduced the metastatic phenotype and reversed the EMT [87].

Regarding bladder cancer, the total and fraction extracts of $N$. sativa were effective in inducing significant morphological changes in human renal adenocarcinoma ACHN cells but not in normal renal epithelial GP-293 cells, stimulating apoptosis and decreasing cell viability in a time and dose dependent manner [88]. Similarly, TQ showed an anticancer effect on human bladder carcinoma T24, 253J and HTB-9 cells, by inducing apoptosis through the promotion of mitochondrial dysfunction and endoplasmic reticulum stress, and by inhibiting EMT via modulation of mTOR signaling, slug, snail, N-cadherin, $\beta$ catenin and Wnt/ $\beta$-catenin expressions [89-91]; interestingly, TQ showed no effect on normal cells (human dermal fibroblasts) [89].

To the best of our knowledge, two in vivo studies were performed on mice: the first highlighted the anticarcinogenic mechanism of TQ in tumor xenograft nude mice by blocking EMT through the downregulation of $\mathrm{N}$-cadherin, $\beta$-catenin and vimentin proteins and suppressed lung metastasis [90], the latter showed the ability of TQ in inducing apoptosis through pro-oxidant effects in tumor xenograft nude mice [86].

\subsection{Skin Cancer}

There are three main types of skin cancer: squamous cell carcinoma, basal cell carcinoma and melanoma, whose epidemiological characteristics, clinical classifications and treatment methods are different [92]. Since skin cancer is frequently resistant to radiotherapy and chemotherapy, the development of cost-effective, novel and efficient treatment methods is urgently needed. Recently, natural compounds have showed potential activities against skin cancer [93]. In this context, in human melanoma MDA-MB-435 cells and in epidermoid carcinoma A431 cells TQ reduced cell viability, promoted apoptosis and cell cycle arrest, suppressed cell proliferation by upregulating the Bax/Bcl-2 ratio, caspases and cleavage of PPAR and downregulating Akt and c-Jun N-terminal kinase (JNK) phosphorylation, and induced chromatin condensation, DNA fragmentation [40,94]; on the contrary, in human keratinocyte cell line $\mathrm{HaCaT} \mathrm{TQ}$ treatment showed no cytotoxic and apoptotic effect, and morphological change [94]. In addition, TQ, the conjugates of TQ with various sesquiterpenes, monoterpenes and triterpene betulinic acid showed antiproliferative activities via ROS mediated apoptosis associated with DNA laddering on 518A2 melanoma cells [83].

\subsection{Ovarian Cancer}

The most common cause of death from gynecologic malignancies is ovarian cancer since many women with epithelial ovarian cancers are diagnosed with advanced, metastatic disease characterized by carcinomatosis and abdominal ascites. In the last decade, TQ has showed an antiproliferative effect in in vitro and in vivo models against ovarian cancer. In murine ID8-NGL ovarian cancer cells, treatment with TQ decreased cell proliferation with the induction of apoptosis by increasing p-p65 and reducing Ki67, PCNA and break downing PARP; it also suppressed the NF- $\kappa \beta$ pathway and the expression of TNF- $\alpha$ and IL-1 $\beta$ [95]. Moreover, TQ analogs showed a significant antiproliferative effect on human adenocarcinoma OVCAR-8 and CIS-A2780 cells more than the patent parent molecule [96].

Regarding in vivo studies, TQ has been shown to suppress tumor cell growth in a mouse model of ovarian cancer cells by inhibiting NF- $\kappa \beta$ activation [97], while in a syngeneic mouse model of ovarian cancer (ID8-NGL mouse C57BL/ 6 cells) the efficacy of TQ was limited in the protumorigenic microenvironment, highlighting the need of prolonged TQ treatment (>30 days) as a harmful factor for its efficacy [95]. 


\subsection{Prostate Cancer}

Prostate cancer is the most common cancer in men and the range of clinical behavior varies from a microscopic, well-differentiated tumor to an aggressive, invasive cancer, which finally results in metastases. TQ is a potential candidate that regulates several major signaling pathways and crucial oncogenic molecules that play a central role in prostate cancer initiation, progression, invasion, metastasis and angiogenesis stage. For example, it turned EMT by raising E-cadherin expression and reducing vimentin and Slug expression, via downregulation of the TGF- $\beta / \mathrm{Smad} 2 / 3$ signaling pathway, and promoted apoptosis by modulating PI3K-AKT pathway in human prostate carcinoma DU145 and PC3 cells [98,99]. In human prostate carcinoma LnCaP cells, TQ deceased cell viability and increased apoptosis by activating caspase-9 [100], and inhibited the growth of human prostate $\mathrm{C} 4-2 \mathrm{~B}$ cancer cells with the activation of JNK and growth arrest and DNA damage inducible gene (GADD45a), upregulating induce apoptosis factor-1 and decreasing Bc12related proteins, such as BAG-1, Bcl2, Bcl2A1, Bcl2L1 and BID [101]. Finally, TQ showed prooxidant cytotoxic mechanism by oxidative DNA damage through copper-dependent pathway via mobilizing and reducing endogenous cellular copper in different prostate cancer cell lines, including DU145, LNCaP, PC3 and C42B [102].

\subsection{N. sativa and Other Cancers}

Many in vitro and in vivo studies have also confirmed the anticancer activities of $N$. sativa and TQ in other types of cancer. For example, TQ decreased chemoresistance and angiogenesis through blocking NF- $\mathrm{K} \beta$ activation, DNA-binding activity, survivin and VEGF and increased the expression of cleaved caspase- 3 and Smac in human osteosarcoma cells SaOS-2121; these results were confirmed in an in vivo study on male athymic BALB/c $\mathrm{nu} / \mathrm{nu}$ mice treated with $\mathrm{TQ}$, where it was able to prevent tumor angiogenesis and inhibit osteosarcoma growth through decreasing the expression of inhibitor of apoptosis proteins, VEGF, prosurvival molecules, such as survivin and XIAP, and proliferation markers, including CD34 and Ki-67 [103]. Moreover, it suppressed osteolytic bone metastasis, such as bone marrow of the femora, tibiae, mandibles and osteolytic lesions in NCr-Foxn1nu female mice injected with breast MDA-MB-231-lucC cancer cells into the left cardiac ventricle [39]. Moreover, volatile oil of N. sativa has shown chemopreventive potential in fibrous histiosarcoma by decreasing malignant tumor sizes, incidences and multiplicities in carcinogens-treated rats [104].

It has been reported that TQ showed anticancer activity also in oral cancer, by downregulating p $38 \beta$ MAPK in oral T28 cancer cells, by increasing the expression of the proapoptotic proteins Bad and Bid and activating p53 and caspase 3 cleavage [105]. It was responsible for apoptosis and autophagy-mediated cell death in oral cancer SCC-4, SAS, SASVO3, OC2 and B S-G cells, where it modulated Bax expression and caspase-9 activation, autophagic vacuoles and LC3-II proteins by caspase activation-dependent apoptosis [106]. Regarding in vivo studies, TQ has been shown an antitumor effect in BALB/c nude mouse xenograft model by inducing apoptosis and autophagy [106] and in DMBA treated hamster buccal pouch carcinogenesis through repaired expression of cytokeratin and suppressed tumor formation [107].

$N$. sativa seed oil has shown anticancer activities also in brain U87 cancer cells through the degradation of $\alpha / \beta$ tubulin with the upregulation of the tumor suppressor p73 gene and induction of apoptosis [78]. In addition, it also induced cellular senescence in human malignant glioma cells U87MG, U118MG and A172 by suppressing cell cycle progression in the G1 phase, and increasing p53, p21, Rb and reduced lamin B1, cyclin E and CDK-2 [108].

Finally, TQ acted as a potent agent in the treatment of head and neck cancer by exerting antiproliferative and radio sensitizing properties through the decrease of colony formation and the induction of apoptosis in tongue carcinoma SCC25, CAL27 and HNSCC cells [109].

Table 3 summarizes the anticancer effects exerted by N. sativa and its main components in different types of cancers. 
Table 3. Anticancer activities of N. sativa and its main component thymoquinone in different cancer types.

\begin{tabular}{|c|c|c|c|c|}
\hline $\begin{array}{c}\text { N. sativa } \\
\text { Extracts/Fraction/ } \\
\text { Component/Analogs }\end{array}$ & Experimental Models & Intervention & Main Results & References \\
\hline \multicolumn{5}{|l|}{ Breast cancer } \\
\hline \multicolumn{5}{|l|}{ In vitro } \\
\hline Thymoquinone & MCF-7 and MDA-MB-231 & $40 \mu \mathrm{M}$ for $12 \mathrm{~h}$ & $\begin{array}{ll}- & \text { Decrease of cell proliferation } \\
- & \text { Induction of apoptosis } \\
- & \text { Increase of ROS }\end{array}$ & [35] \\
\hline Thymoquinone & $\begin{array}{l}\text { MDA-MB-468 and T-47D } \\
\text { cells }\end{array}$ & $\begin{array}{l}0.01-60 \mu \mathrm{M} \text { for } \\
12,24 \text { and } 48 \mathrm{~h}\end{array}$ & $\begin{array}{ll}- & \text { Decrease of cell proliferation } \\
- & \text { Induction of apoptosis and } \\
\text { arrest cell }\end{array}$ & [36] \\
\hline Proteins from black seeds & MCF-7 cells & $\begin{array}{l}5-60 \mu \mathrm{g} / \mathrm{mL} \\
\text { for } 48 \mathrm{~h}\end{array}$ & $\begin{array}{ll}- & \text { Inhibition of cell proliferation } \\
- & \text { Induction of apoptosis } \\
- & \text { Arrest of cell cycle }\end{array}$ & [37] \\
\hline Thymoquinone & $\begin{array}{c}\text { MCF-7, MDA-MB-231 and } \\
\text { BT- } 474 \text { cells }\end{array}$ & $\begin{array}{c}48,40 \text { and } 32 \mathrm{mM}, 24,14 \\
\text { and } 11 \mathrm{mM}, 38,18 \text {, and } \\
21 \mathrm{mM} \text { for } 12,24 \text { and } 48 \mathrm{~h}\end{array}$ & $\begin{array}{ll}- & \begin{array}{l}\text { Inhibition of cell } \\
\text { proliferation via }\end{array} \\
- & \text { PPAR- activation pathway } \\
- & \text { Induction of apoptosis } \\
- & \begin{array}{l}\text { Reduction of the migration } \\
\text { and invasion }\end{array}\end{array}$ & [38] \\
\hline Thymoquinone & $\begin{array}{c}\text { MCF7, MDA-MB-231, and } \\
\text { BT-549 cells }\end{array}$ & $25,50 \mu \mathrm{M}$ for $24 \mathrm{~h}$ & $\begin{array}{l}\text { - } \quad \text { Reduction of the migration } \\
\text { and invasion } \\
\text { - } \quad \begin{array}{l}\text { Inhibition of tumor growth } \\
\text { and metastasization }\end{array}\end{array}$ & [39] \\
\hline Thymoquinone & $\begin{array}{c}\text { Mouse breast cancer cell } \\
\text { line } 4 \mathrm{~T} 1\end{array}$ & $5 \mu \mathrm{M}$ for $6 \mathrm{~h}$ & $\begin{array}{l}\text { - Inhibition of cell growth, } \\
\text { migration and invasion } \\
\text { - } \quad \text { Down-regulating of N-Cadherin } \\
\text { and upregulation of } \\
\text { E-cadherin expression }\end{array}$ & [40] \\
\hline Thymoquinone & $\begin{array}{l}\text { MDA-MB-231 and } \\
\text { MDAMB-468 }\end{array}$ & $2.5-5 \mu \mathrm{M}$ for $72 \mathrm{~h}$ & $\begin{array}{ll}- & \text { Inhibition of cell growth } \\
- & \text { Induction of apoptosis } \\
- & \text { Arrest of cell cycle at G1 phase } \\
- & \text { Reduction of mitochondrial } \\
& \text { membrane integrity }\end{array}$ & [41] \\
\hline Thymoquinone & MCF-7 cells & $100 \mu \mathrm{M}$ for $48 \mathrm{~h}$ & $\begin{array}{ll}\text { - } & \text { Induction of apoptosis } \\
\text { - } & \text { Disruption of mitochondrial } \\
\text { membrane potential } \\
\text { - } & \text { Activation of caspases and } \\
\text { PARP cleavage } \\
\text { - } \quad \text { Arrest of cell cycle at G2/M and } \\
\text { sub-G1 phase via the } \\
\text { modulation of Akt/PTEN axis }\end{array}$ & [42] \\
\hline \multicolumn{5}{|l|}{ In vivo } \\
\hline Thymoquinone & $\begin{array}{l}\text { NCr-Foxn1nu, female } \\
\text { mice injected with } \\
\text { MDA-MB-231-Luc + cells }\end{array}$ & $\begin{array}{l}2 \mathrm{mg} \text { or } 4 \mathrm{mg} / \mathrm{kg} \\
\text { body weight for } 4 \text { weeks }\end{array}$ & - $\quad$ Suppression of bone metastasis & [39] \\
\hline $\begin{array}{l}\text { N. sativa emulsion of oil } \\
\text { fraction }\end{array}$ & $\begin{array}{l}\text { Six-week-old female } \\
\text { Sprague-Dawley rats }\end{array}$ & $400 \mathrm{mg} / 100 \mathrm{~g}$ for 3 months & $\begin{array}{ll}- & \text { Increase of tumor cell loss } \\
- & \text { Reduction of oxidative damage } \\
- & \text { Decrease of endocrine } \\
\text { derangement }\end{array}$ & [43] \\
\hline \multicolumn{5}{|l|}{ Colon cancer } \\
\hline In vitro & & & & \\
\hline
\end{tabular}


Table 3. Cont

\begin{tabular}{|c|c|c|c|c|}
\hline $\begin{array}{c}\text { N. sativa } \\
\text { Extracts/Fraction// } \\
\text { Component/Analogs }\end{array}$ & Experimental Models & Intervention & Main Results & References \\
\hline $\begin{array}{l}\alpha \text {-hederin and } \\
\text { thymoquinone }\end{array}$ & HT-29 cells & $\begin{array}{c}6-40 \mu \mathrm{M} \text { (Alpha) and } \\
25-150 \mu \mathrm{M}(\mathrm{TQ}) \\
\text { for } 24,48 \text { and } 72 \mathrm{~h}\end{array}$ & $\begin{array}{ll}- & \text { Decrease of cell proliferation } \\
\text { - } & \text { Induction of apoptosis and } \\
\text { necrosis }\end{array}$ & [44] \\
\hline Thymoquinone & CPT-11-R LoVo cells & $2-8 \mu \mathrm{M}$ for $24 \mathrm{~h}$ & $\begin{array}{ll}\text { - } & \text { Increase of autophagic cell death } \\
\text { - } & \text { Activation of apoptosis }\end{array}$ & [45] \\
\hline Thymoquinone & CPT-11-R LoVo cells & $2,4,6$, and $8 \mu \mathrm{M}$ for $24 \mathrm{~h}$ & $\begin{array}{l}\text { - } \quad \text { Suppression of metastasis by } \\
\text { NF- } k \beta \text { inhibition and activation } \\
\text { of JNK and } \mathrm{p} 38\end{array}$ & [46] \\
\hline Thymoquinone & $\begin{array}{l}\text { Caco-2, HCT-116, LoVo, } \\
\text { DLD-1 and HT-29 cells }\end{array}$ & $12.5-110 \mu \mathrm{M}$ for 24 and $48 \mathrm{~h}$ & $\begin{array}{ll}- & \text { Inhibition of cell growth } \\
- & \text { Induction of apoptosis via ROS } \\
\text { generation }\end{array}$ & [47] \\
\hline Thymoquinone & LoVo cells & 5-20 $\mu \mathrm{mol} / \mathrm{L}$ for $24 \mathrm{~h}$ & $\begin{array}{l}\text { - Inhibition of cancer cell growth } \\
\text { and migration }\end{array}$ & [48] \\
\hline Thymoquinone & HCT116 cells & $0.1 \mathrm{~mL}$ for $24 \mathrm{~h}, 48 \mathrm{~h}$ and $72 \mathrm{~h}$ & $\begin{array}{ll}\text { - } & \text { Induction of apoptosis by } \\
\text { blocking } \\
\text { - } & \text { STAT3 pathway }\end{array}$ & [49] \\
\hline $\begin{array}{l}\text { N. sativa } \\
\text { Thymoquinone } \\
\text { All-trans-retinol plus } \\
\text { Selenium } \\
\text { DL- } \alpha \text {-tocopherol }\end{array}$ & $\begin{array}{l}\text { AOM treated male } \\
\text { Sprague Dawley rats }\end{array}$ & $\begin{array}{l}200 \mathrm{mg} / \mathrm{kg} \text { for } 5 \text { weeks } \\
0.2 \mathrm{mg} / \mathrm{kg} \text { for } 5 \text { weeks } \\
1.2 \mathrm{mg} / \mathrm{kg} \text { for } 5 \text { weeks } \\
100 \mathrm{mg} / \mathrm{kg} \text { for } 5 \text { weeks } \\
10 \mathrm{mg} / \mathrm{kg} \text { for } 5 \text { weeks }\end{array}$ & $\begin{array}{ll}\text { - } & \text { Inhibition of oxidative DNA } \\
\text { damage } \\
\text { - } \quad \text { Inhibition of liver MDA }\end{array}$ & [50] \\
\hline Thymoquinone & PGE2 treated nude mice & $\begin{array}{c}0.5,10 \text { and } 20 \mu \mathrm{mol} / \mathrm{L} / \\
3 \text { time/week for three weeks }\end{array}$ & $\begin{array}{ll}\text { - } & \text { Inhibition of metastasization } \\
- & \text { Inhibit of tumor growth }\end{array}$ & [49] \\
\hline Thymoquinone & $\begin{array}{l}\text { DMH treated male Albino } \\
\text { Wistar rats }\end{array}$ & $10 \mathrm{mg} / \mathrm{kg} /$ day & $\begin{array}{ll}- & \text { Inhibition of cellular } \\
\text { proliferation } \\
- & \text { Decrease of PCNA and VEGF } \\
- & \text { Suppression of cancer invasion }\end{array}$ & [51] \\
\hline \multicolumn{5}{|l|}{ Hepatic Cancer } \\
\hline \multicolumn{5}{|l|}{ In vitro } \\
\hline $\begin{array}{l}\text { Alcoholic extracts of } N \text {. } \\
\text { sativa }\end{array}$ & HepG2 cells & $\begin{array}{l}1000,2500 \text {, and } 5000 \mu \mathrm{g} / \mathrm{mL} \\
\quad \text { for } 6,24,48 \text {, and } 72 \mathrm{~h}\end{array}$ & $\begin{array}{ll}\text { - } & \text { Improvement of antioxidant } \\
\text { status } & \\
\text { - } & \text { Induction of apoptotic death }\end{array}$ & [52] \\
\hline Thymoquinone & HepG2 cells & $6-50 \mu \mathrm{M}$ for $6,12,18 \mathrm{~h}$ & $\begin{array}{ll}\text { - } & \text { Induction of cell cycle arrest at } \\
\text { G2/M phase } \\
\text { - } \\
\text { Enhancement of TRAIL-induced } \\
\text { cell death } \\
\text { - } \quad \text { Stimulation of pro-apoptotic } \\
\text { Bcl-xS } \\
\text { - } \quad \text { Inhibition of cell growth }\end{array}$ & [53] \\
\hline Thymoquinone & HepG2 cells & $\begin{array}{c}20,40,60,80 \text { and } \\
100 \mu \mathrm{M} \text { for } 24,48 \text { and } \\
72 \mathrm{~h}\end{array}$ & $\begin{array}{ll}\text { - } & \text { Arrest of cell cycle at G2/M } \\
\text { phase } \\
\text { - } & \text { Induction of apoptosis } \\
\text { - } & \text { Decrease of VEGF }\end{array}$ & [54] \\
\hline Thymol and cravacol & HepG2 cells & $\begin{array}{c}25,50 \text {, and } 100 \mathrm{mM} \text { for } 24,48, \\
72 \mathrm{~h}\end{array}$ & $\begin{array}{l}\text { Improvement of oxidative stress } \\
\text { and inflammation }\end{array}$ & [55] \\
\hline \multicolumn{5}{|l|}{ In vivo } \\
\hline N. sativa extract & $\begin{array}{l}\text { DENA induced } \\
\text { preneoplastic stage of } \\
\text { HCC in rats }\end{array}$ & $\begin{array}{l}150,250,350 \mathrm{mg} / \mathrm{kg} / \text { day } \\
\text { body weight for } 16 \text { weeks }\end{array}$ & $\begin{array}{ll}- & \text { Antioxidant effects } \\
- & \text { Inhibition of EGFR/ERK1/2 } \\
\text { pathway }\end{array}$ & [56] \\
\hline
\end{tabular}


Table 3. Cont

\begin{tabular}{|c|c|c|c|c|}
\hline $\begin{array}{c}\text { N. sativa } \\
\text { Extracts/Fraction/ } \\
\text { Component/Analogs }\end{array}$ & Experimental Models & Intervention & Main Results & References \\
\hline Thymoquinone & $\begin{array}{l}\text { DENA induce male Wistar } \\
\text { albino rats }\end{array}$ & $4 \mathrm{mg} / \mathrm{kg} /$ day for 7 days & $\begin{array}{ll}\text { - } & \text { Increase of antioxidant activity } \\
- & \text { Control of cell proliferation }\end{array}$ & [57] \\
\hline N. sativa extract & $\begin{array}{l}\text { DENA-induced } \\
\text { hepatocarcinogenesis } \\
\text { Male Wistar rats }\end{array}$ & $250 \mathrm{mg} / \mathrm{kg} /$ day for 5 days & $\begin{array}{l}\text { Reduction of serum levels of } \\
\text { alpha-fetoprotein, TNF- } \alpha \text {, IL-6 } \\
\text { levels NO and iNOS activity }\end{array}$ & [58] \\
\hline Thymoquinone & $\begin{array}{l}\text { NDEA induce male Wistar } \\
\text { strain albino rats }\end{array}$ & $20 \mathrm{mg} / \mathrm{kg}$ body weight & $\begin{array}{ll}- & \text { Decrease of cell proliferation } \\
- & \text { Regulation of G1/S phase } \\
- & \text { cell cycle transition } \\
- & \text { Decrease of tumor markers } \\
- & \text { Inhibition of hepatic nodule } \\
& \text { formation } \\
- & \text { Reduction of tumor multiplicity }\end{array}$ & [59] \\
\hline \multicolumn{5}{|l|}{ Lung cancer } \\
\hline \multicolumn{5}{|l|}{ In vitro } \\
\hline Thymoquinone & A549 cells & $\begin{array}{l}25,50 \text { and } 100 \mu \mathrm{M} \\
\text { For } 72 \mathrm{~h}\end{array}$ & $\begin{array}{ll}- & \text { Reduction of viability } \\
- & \text { Increase of apoptotic cell death }\end{array}$ & [60] \\
\hline Thymoquinone & $\begin{array}{l}\text { NCI-H460 and } \\
\text { NCI-H146 cells }\end{array}$ & $\begin{array}{l}20,40,60,80 \text { and } \\
100 \mu \mathrm{M} \text { for } 24 \mathrm{~h}\end{array}$ & $\begin{array}{ll}- & \text { Reduction of cell viability } \\
- & \text { Induction of apoptosis }\end{array}$ & [61] \\
\hline Thymoquinone & A549 cells & $\begin{array}{l}5,10,20,40,80,160 \mu \mathrm{mol} / \mathrm{L} \\
\text { for } 24,48 \text {, or } 72 \mathrm{~h}\end{array}$ & $\begin{array}{ll}\text { - } & \begin{array}{l}\text { Inhibition of metastasization } \\
\text { Inhibition of proliferation, }\end{array} \\
\text { migration, } \\
\text { and invasion via ERK1/2 } \\
\text { pathway }\end{array}$ & [62] \\
\hline Thymoquinone & A549 cells & $10,25 \mu \mathrm{M}$ for $24 \mathrm{~h}$ & $\begin{array}{ll}\text { - } & \text { Induction of G2/M cell cycle } \\
\text { arrest } \\
- & \text { and apoptosis } \\
- & \text { Depolymerization of } \\
\text { microtubule network }\end{array}$ & [63] \\
\hline
\end{tabular}

In vivo

Thymoquinone

Thymoquinone

MUC4 expressed

FG/COLO357 and

CD18/HPAF cells
HS766T cells
$8 \mathrm{mg} / \mathrm{kg}, 12 \mathrm{mg} / \mathrm{kg}$, $16 \mathrm{mg} / \mathrm{kg} /$ day for 2 weeks
Induction of apoptosis

Inhibition of pulmonary arterial remodeling

via p38MAPK/NF- $\mathrm{KB}$ signaling pathway

Inhibition of cell growth

Downregulation of MUC4

expression

Induction of apoptosis

Upregulation of p21

Suppression of histone

deacetylase activity,

Decrease of MCP-1, TNF- $\alpha$,

IL-1b and Cox- 2 via NF-k $\beta$

modulation

Inhibition of cell growth

Thymoquinone-2G,

MiaPaCa-2, BxPC-3,

AsPC-1

and HPAC

$10 \mu \mathrm{M}$ for $72 \mathrm{~h}$
G2/M phase cell-cycle arrest
Modulation of NF- $\mathrm{KB}$

transcription 
Table 3. Cont

\begin{tabular}{|c|c|c|c|c|}
\hline $\begin{array}{c}\text { N. sativa } \\
\text { Extracts/Fraction/ } \\
\text { Component/Analogs }\end{array}$ & Experimental Models & Intervention & Main Results & References \\
\hline \multicolumn{5}{|l|}{ Pancreatic cancer } \\
\hline \multicolumn{5}{|l|}{ In vitro } \\
\hline ATQTHB and ATQTFB & $\begin{array}{l}\text { MiaPaCa-2 } \\
\text { and BxPC-3 cells }\end{array}$ & $5,10,25 \mu \mathrm{M}$ for $72 \mathrm{~h}$ & Decrease of cell proliferation & [68] \\
\hline \multicolumn{5}{|l|}{ Cervical cancer } \\
\hline \multicolumn{5}{|l|}{ In vitro } \\
\hline $\begin{array}{l}\text { Organic extracts of } \\
\text { N. sativa (methanolic, } \\
\text { n-hexane, and } \\
\text { chloroform extracts) }\end{array}$ & HeLa cells & $21.1 \%, 30 \%$ and $42 \%$ for $24 \mathrm{~h}$ & $\begin{array}{l}\text { Induction of apoptosis by the } \\
\text { modulation } \\
\text { of pro- and anti-apoptotic gene }\end{array}$ & [69] \\
\hline $\begin{array}{l}\text { N. sativa oil fraction } \\
\text { and thymoquinone }\end{array}$ & HeLa cells & $\begin{array}{l}0.03 \text { to } 2 \mu \mathrm{L} / \mathrm{mL} \text { and } \\
6.25 \text { to } 100 \mu \mathrm{M} \text { for } 48 \mathrm{~h}\end{array}$ & $\begin{array}{ll}- & \text { Inhibition of cell proliferation } \\
- & \text { and migration } \\
- & \text { Induction of apoptosis }\end{array}$ & [70] \\
\hline Thymoquinone & SiHa cells & $\begin{array}{l}\text { to } 30 \mu \mathrm{g} / \mathrm{mL} \text { for } \\
24,48 \text { and } 72 \mathrm{~h}\end{array}$ & $\begin{array}{ll}- & \text { Decrease of cell viability } \\
- & \text { Arrest of cell cycle at sub-G1 } \\
\text { - } & \text { phase } \\
\text { Promotion of apoptosis }\end{array}$ & {$[71,72]$} \\
\hline Thymoquinone & $\begin{array}{l}\text { SiHa and } \\
\text { C33A cells }\end{array}$ & $10-100 \mu \mathrm{M}$ for $22 \mathrm{~h}$ & Induction of apoptosis & [73] \\
\hline Thymoquinone & $\mathrm{SiHa}$ and $\mathrm{CaSki}$ & $\begin{array}{l}1,5,10,20 \text { and } 40 \mu \mathrm{M} \\
\text { for } 12,24,36 \text { and } 48 \mathrm{~h}\end{array}$ & $\begin{array}{ll}- & \text { Suppression of cell growth } \\
- & \text { Induction of apoptosis } \\
- & \text { Inhibition of migration and } \\
\text { invasion }\end{array}$ & [74] \\
\hline Poloxin & HeLa cells & 5-25 $\mu \mathrm{M}$ for & $\begin{array}{l}\text { - } \quad \text { Suppression of serine/threonine } \\
\text { kinase Polo-like kinase } 1 \text { (Plk1) }\end{array}$ & [75] \\
\hline \multicolumn{5}{|l|}{ Leukemia/Blood cancer } \\
\hline \multicolumn{5}{|l|}{ In vitro } \\
\hline Thymoquinone & Jurkat cells & 10 and $20 \mu \mathrm{M}$ for $24 \mathrm{~h}$ & Promotion of apoptosis & [76] \\
\hline Thymoquinone & CEMss cell & $\begin{array}{l}50,25,12.5,6,3 \text { and } 1.5 \mu \mathrm{g} / \mathrm{mL} \\
\text { for } 24,48,72 \mathrm{~h}\end{array}$ & $\begin{array}{ll}- & \text { Decrease of cell viability } \\
- & \text { Arrest of cell cycle at S phase } \\
- & \text { Promotion of apoptosis } \\
- & \text { Breakdown of cellular DNA }\end{array}$ & [77] \\
\hline Thymoquinone & Jurkat cells & $100 \mathrm{mM}$ for $24 \mathrm{~h}$ & Degradation of $\alpha / \beta$ Tubulin & [78] \\
\hline Thymoquinone & $\begin{array}{l}\text { Kasumi-1, MV4-11, THP-1 } \\
\text { and ML-1 }\end{array}$ & $\begin{array}{l}1,10,30 \text { and } 300 \mathrm{nM}, 1,3, \\
10,30 \text { and } 100 \mu \mathrm{M} \text { for } 24 \mathrm{~h}\end{array}$ & $\begin{array}{ll}- & \text { Inhibition of cancer cell growth } \\
- & \text { Decrease of DNMT1 methylation } \\
- & \text { Decrease of colony formation } \\
- & \text { Increase of cell apoptosis }\end{array}$ & [79] \\
\hline Thymoquinone & Murine WEHI- 3 cells & $\begin{array}{l}100,50,25,12.5,6,3 \\
\text { and } 1.5 \mathrm{mg} / \mathrm{mL} \text { for } 24 \mathrm{~h}\end{array}$ & $\begin{array}{ll}- & \text { Decrease of cell viability } \\
- & \text { Promotion of apoptosis }\end{array}$ & [80] \\
\hline Thymoquinone & Jurkat cells & $5-10 \mu \mathrm{M}$ for $24 \mathrm{~h}$ & $\begin{array}{l}\text { Upregulation of tumor } \\
\text { suppressor genes }\end{array}$ & [81] \\
\hline Thymoquinone & MDN and XG-2 cell lines & $0.5-50 \mu \mathrm{M}$ for $0.25-48 \mathrm{~h}$ & $\begin{array}{ll}\text { - } & \text { Inhibition of CXCL12 mediated } \\
\text { chemotaxis } \\
\text { - }\end{array}$ & [82] \\
\hline $\begin{array}{l}\text { Thymoquinone } \\
\text { derivatives bound to } \\
\text { terpene residues }\end{array}$ & Human HL-60 leukemia & $5 \mu \mathrm{M}$ for $72 \mathrm{~h}$ & $\begin{array}{ll}- & \text { Decrease of cell proliferation } \\
- & \text { Induction of apoptosis } \\
\text { associated } \\
\text { - } & \text { with DNA laddering } \\
\text { - } & \text { Increase in ROS }\end{array}$ & [83] \\
\hline
\end{tabular}


Table 3. Cont

\begin{tabular}{|c|c|c|c|c|}
\hline $\begin{array}{c}\text { N. sativa } \\
\text { Extracts/Fraction/ } \\
\text { Component/Analogs }\end{array}$ & Experimental Models & Intervention & Main Results & References \\
\hline Thymoquinone & C57BL/ 6 mice & $\begin{array}{c}15 \text { and } 30 \mathrm{mg} / \mathrm{kg} / 2 \\
\text { dose } / \text { week } \\
\text { for } 3 \text { weeks }\end{array}$ & $\begin{array}{ll}- & \text { Reversion of splenomegaly } \\
- & \text { Inhibition of leukemia cell } \\
& \text { growth in lungs and livers }\end{array}$ & [79] \\
\hline Thymoquinone & $\mathrm{BALB} / \mathrm{c}$ mice & $\begin{array}{l}100 \mathrm{mg} / \mathrm{mL}, 50 \mathrm{mg} / \mathrm{kg} \text { for } \\
3 \text { weeks }\end{array}$ & Inhibition of tumor growth & [80] \\
\hline \multicolumn{5}{|l|}{ Urinary cancer } \\
\hline \multicolumn{5}{|l|}{ In vitro } \\
\hline Thymoquinone & Caki cells & 25,50 and $75 \mu \mathrm{M}$ for $24 \mathrm{~h}$ & $\begin{array}{ll}\text { - } & \text { Induction of apoptosis through } \\
\text { downregulating c-FLIP and Bcl-2 } \\
\text { - } & \text { Increase of intracellular ROS }\end{array}$ & [84] \\
\hline Thymoquinone & Caki-1, Caki-2, A498 cells & $0.5-10 \mu \mathrm{M}$ for $24,48 \mathrm{~h}$ & $\begin{array}{ll}- & \text { Induction of apoptosis } \\
- & \text { Decrease of HIF-1 protein }\end{array}$ & [85] \\
\hline Thymoquinone & Caki- 1 cells & $1-25 \mu \mathrm{M}$ for $24 \mathrm{~h}$ & $\begin{array}{ll}\text { - } & \text { Increase of intracellular ROS } \\
- & \text { Induction of apoptosis }\end{array}$ & [86] \\
\hline Thymoquinone & 786-O and RCC 769-P cells & $\begin{array}{c}0,10,20,40,60,80 \text { and } \\
100 \mu \mathrm{mol} / \mathrm{L} \text { for } 24 \mathrm{~h} \text { or } 48 \mathrm{~h}\end{array}$ & $\begin{array}{l}\text { - Inhibition of metastatic cell } \\
\text { growth via AMPK/mTOR } \\
\text { signaling pathway }\end{array}$ & [87] \\
\hline $\begin{array}{l}\text { Hydroalcoholic extract of } \\
\text { N. sativa and its fraction }\end{array}$ & ACHN cells & $\begin{array}{c}50,100,250,500,750,1000 \\
1250,1500,1750, \text { and } 2000 \\
\mathrm{mg} / \mathrm{mL} \\
\text { for } 24,48 \text { and } 72 \mathrm{~h}\end{array}$ & $\begin{array}{ll}\text { - } & \text { Decrease of cell viability } \\
\text { - } & \text { Promotion of apoptosis }\end{array}$ & [88] \\
\hline Thymoquinone & T24 and HTB-9 cells & 10 to $75 \mu \mathrm{M}$ for $48 \mathrm{~h}$ & $\begin{array}{ll}\text { - } & \text { Decrease of cell viability } \\
- & \text { Inhibition of EMT by mTOR } \\
& \text { signaling }\end{array}$ & [89] \\
\hline Thymoquinone & $\begin{array}{l}\text { T24 and } 253 \mathrm{~J} \text { bladder } \\
\text { cancer cells }\end{array}$ & $\begin{array}{c}10-40 \mu \mathrm{M} \text { for } \\
24 \mathrm{~h}\end{array}$ & $\begin{array}{ll}\text { - } & \text { Decrease of cell viability and } \\
\text { proliferation } \\
-\quad & \text { Decrease of metastasization } \\
- & \text { Reverse of EMT }\end{array}$ & [90] \\
\hline Thymoquinone & $\begin{array}{l}\text { T24 and } 253 \mathrm{~J} \text { bladder } \\
\text { cancer cells }\end{array}$ & $\begin{array}{c}40-80 \mu \mathrm{mol} / \mathrm{L} \text { for } \\
24 \mathrm{~h}\end{array}$ & $\begin{array}{ll}\text { - } & \text { Decrease of cell viability and } \\
\text { proliferation } \\
\text { - } & \text { Induction of endoplasmic } \\
\text { reticulum stress-mediated } \\
\text { apoptosis }\end{array}$ & [91] \\
\hline \multicolumn{5}{|l|}{ In vivo } \\
\hline Thymoquinone & male BALB/c nude mice & $\begin{array}{c}1 \mathrm{mg} / \mathrm{kg} \text { or } 5 \mathrm{mg} / \mathrm{kg} \text { for } 3 \\
\text { times/day for } 35 \text { days }\end{array}$ & $\begin{array}{ll}- & \text { Decrease of tumor volume } \\
- & \text { Induction of pro-oxidant effect }\end{array}$ & [86] \\
\hline Thymoquinone & nude mice & $\begin{array}{c}10 \mathrm{mg} / \mathrm{kg} / \text { every } 3 \text { days for } 21 \\
\text { days }\end{array}$ & $\begin{array}{l}\text { Inhibition of EMT and } \\
\text { metastasis }\end{array}$ & [90] \\
\hline \multicolumn{5}{|l|}{ Skin cancer } \\
\hline \multicolumn{5}{|l|}{ In vitro } \\
\hline Thymoquinone & A431 cells & $2-100 \mu \mathrm{M}$ for 24 or $48 \mathrm{~h}$ & $\begin{array}{ll}- & \text { Inhibition of cell proliferation } \\
- & \text { Induction of apoptosis }\end{array}$ & [94] \\
\hline Thymoquinone & $\begin{array}{l}\text { Melanoma MDA-MB-435 } \\
\text { cells }\end{array}$ & $5 \mu \mathrm{M}$ for $6 \mathrm{~h}$ & $\begin{array}{l}\text { - Inhibition of cell growth, } \\
\text { migration, and invasion }\end{array}$ & [40] \\
\hline $\begin{array}{l}\text { Thymoquinone and its } \\
\text { conjugated derivatives }\end{array}$ & 518A2 melanoma & $3.9 \mu \mathrm{m}$ for $72 \mathrm{~h}$ & $\begin{array}{l}\text { Enhancement of anticancer } \\
\text { activity }\end{array}$ & [83] \\
\hline \multicolumn{5}{|l|}{ Ovarian cancer } \\
\hline In vitro & & & & \\
\hline
\end{tabular}


Table 3. Cont.

\begin{tabular}{|c|c|c|c|c|}
\hline $\begin{array}{c}\text { N. sativa } \\
\text { Extracts/Fraction// } \\
\text { Component/Analogs }\end{array}$ & Experimental Models & Intervention & Main Results & References \\
\hline Thymoquinone & Murine ID8-NGL cells & $25 \mu \mathrm{M}$ for 24 & $\begin{array}{ll}- & \text { Decrease of cell proliferation } \\
- & \text { Induction of apoptosis by } \\
\text { increasing p-p65 and reducing } \\
\text { Ki67, PCNA and break downing } \\
\text { PARP } \\
\text { - Suppression of NF- } \kappa \beta, \text { TNF- } \alpha \\
\text { and IL-1 } \beta\end{array}$ & [95] \\
\hline $\begin{array}{l}\text { Thymoquinone and } \\
\text { its analogs }\end{array}$ & OVCAR- 8 and CIS-A2780 & $10 \mathrm{mM}$ for $24 \mathrm{~h}$ & Induction of cytotoxic effect & [96] \\
\hline \multicolumn{5}{|l|}{ In vivo } \\
\hline Thymoquinone & $\begin{array}{l}\text { ID8-NGL treated C57BL/ } 6 \\
\text { mice }\end{array}$ & $\begin{array}{l}20 \mathrm{mg} / \mathrm{kg} \text { thrice weekly } \\
\text { for } 10 \text { days and } 30 \text { days }\end{array}$ & $\begin{array}{ll}\text { - } & \text { Induction of cytotoxic effects } \\
- & \text { Induction of DNA damage }\end{array}$ & {$[95,97]$} \\
\hline \multicolumn{5}{|l|}{ Prostate cancer } \\
\hline \multicolumn{5}{|l|}{ In vitro } \\
\hline Thymoquinone & $\begin{array}{l}\text { DU-145 and } \\
\text { PC } 3 \text { cells }\end{array}$ & $0.1-10 \mu \mathrm{M}$ for $24 \mathrm{~h}$ & $\begin{array}{ll}\text { - } & \text { Suppression of metastatic } \\
\text { phenotype } \\
\text { - } \quad \text { Reverse of EMT }\end{array}$ & [98] \\
\hline Thymoquinone & DU-145 cells & $60 \mu \mathrm{M}$ for $72 \mathrm{~h}$ & $\begin{array}{ll}- & \text { Promotion of cytotoxicity } \\
- & \text { Induction of apoptosis }\end{array}$ & [99] \\
\hline Thymoquinone & LnCaP cells & $\begin{array}{l}1,5,10,25 \text { and } 50 \mu \mathrm{M} \\
\quad \text { for } 24 \text { or } 48 \mathrm{~h}\end{array}$ & $\begin{array}{ll}- & \text { Decease of cell viability } \\
\text { - } & \text { Increase of apoptosis by } \\
\text { activating caspase-9 }\end{array}$ & [100] \\
\hline Thymoquinone & $\begin{array}{l}\text { C4-2B and } \\
\text { PC- } 3 \text { cells }\end{array}$ & $\begin{array}{l}25-150 \mu \mathrm{mol} / \mathrm{L} \\
\quad \text { for } 24-48 \mathrm{~h}\end{array}$ & $\begin{array}{ll}- & \text { Inhibition of cell growth } \\
- & \text { Increase of intracellular ROS } \\
- & \text { Decrease of GSH levels }\end{array}$ & [101] \\
\hline Thymoquinone & $\begin{array}{l}\text { PC3, LNCaP, DU145 and } \\
\text { C42B cells }\end{array}$ & $0-20 \mu \mathrm{M}$ for $72 \mathrm{~h}$ & $\begin{array}{ll}\text { - } & \text { Induction of oxidative DNA } \\
\text { damage } \\
\text { - }\end{array}$ & [102] \\
\hline
\end{tabular}

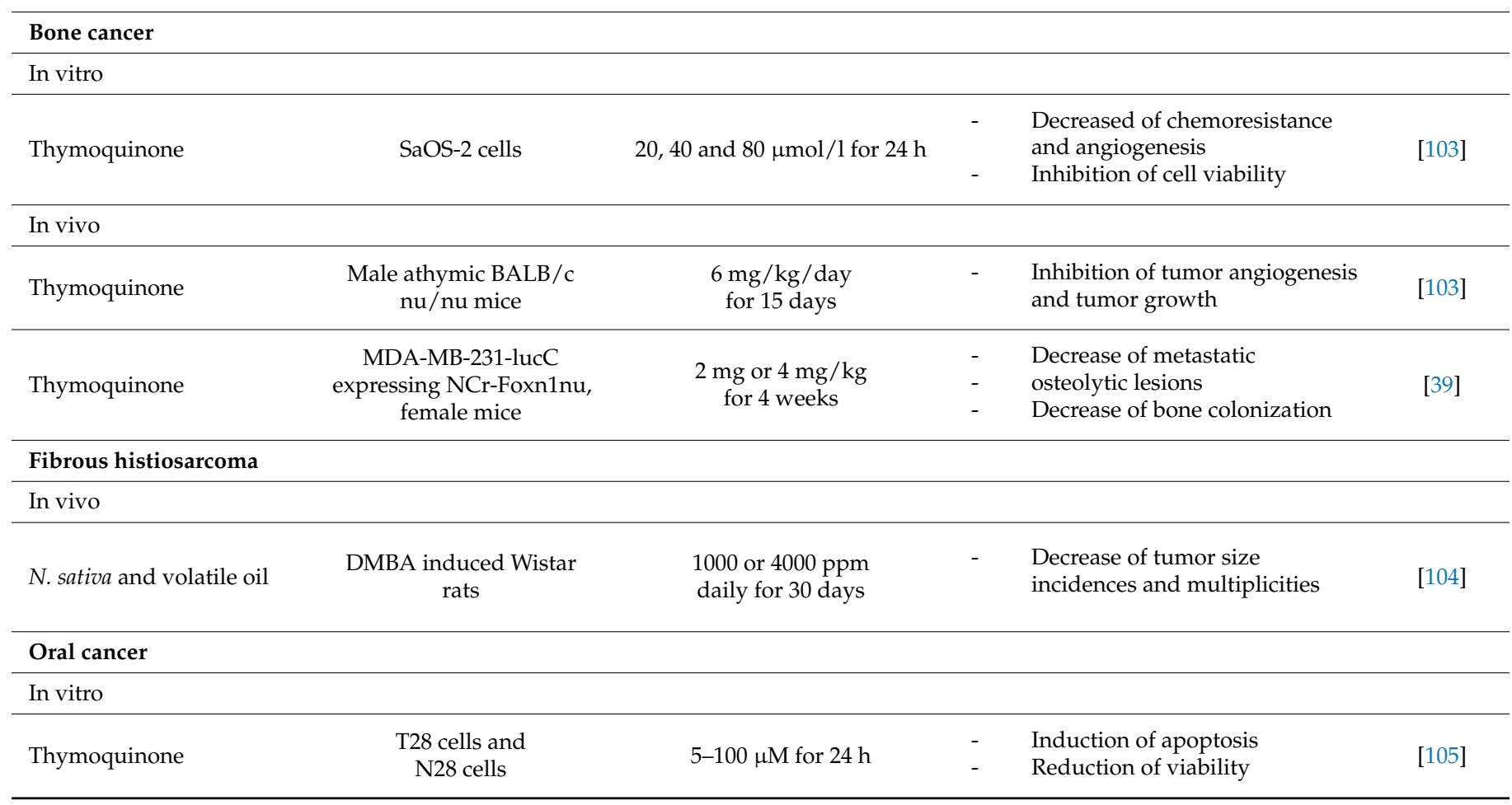


Table 3. Cont

\begin{tabular}{|c|c|c|c|c|}
\hline $\begin{array}{c}\text { N. sativa } \\
\text { Extracts/Fraction/ } \\
\text { Component/Analogs }\end{array}$ & Experimental Models & Intervention & Main Results & References \\
\hline Thymoquinone & $\begin{array}{l}\text { SCC-4, SAS, SASVO3, } \\
\text { OC2, } \\
\text { and (B) S-G cells }\end{array}$ & 20,40 , and $60 \mu \mathrm{M}$ for $24 \mathrm{~h}$ & $\begin{array}{l}\text { - } \begin{array}{l}\text { Induction of autophagic cell } \\
\text { death }\end{array} \\
\text { - } \quad \text { Promotion of } \\
\text { caspase-9-dependent apoptosis }\end{array}$ & [106] \\
\hline \multicolumn{5}{|l|}{ In vivo } \\
\hline Thymoquinone & $\begin{array}{l}\text { BALB/c AnN.CgFoxn } \\
\text { nu /Crl Narl mice }\end{array}$ & $\begin{array}{l}10 \text { and } 25 \mathrm{mg} / \mathrm{kg} \text { body wt } \\
\text { for } 20 \text { days }\end{array}$ & $\begin{array}{l}\text { Reduction of tumor weight and } \\
\text { volume }\end{array}$ & [106] \\
\hline Thymoquinone & $\begin{array}{l}\text { DMBA induced hamster } \\
\text { rats }\end{array}$ & $\begin{array}{c}30 \mathrm{mg} / \mathrm{kg} \text { body wt for } 14 \\
\text { weeks }\end{array}$ & $\begin{array}{ll}\text { - } & \text { Potent chemo preventive efficacy } \\
\text { - } & \text { Prevention of the incidence of } \\
\text { - } & \text { neoplasm and } \\
\text { cytokeratin expression }\end{array}$ & [107] \\
\hline \multicolumn{5}{|l|}{ Brain cancer } \\
\hline \multicolumn{5}{|l|}{ In vitro } \\
\hline Thymoquinone & U87 cells & $100 \mathrm{mM}$ for $24 \mathrm{~h}$ & Degradation of $\alpha / \beta$ Tubulin & [78] \\
\hline Thymoquinone & $\begin{array}{l}\text { U87MG, U118MG, and } \\
\text { A172 cells }\end{array}$ & $10-100 \mu \mathrm{M}$ for $24 \mathrm{~h}$ & Suppression of tumor growth & [108] \\
\hline \multicolumn{5}{|l|}{ Head and neck } \\
\hline \multicolumn{5}{|l|}{ In vitro } \\
\hline Thymoquinone & $\begin{array}{l}\text { SCC25 and CAL27 } \\
\text { HNSCC cells }\end{array}$ & $0-80 \mu \mathrm{M}$ for $72 \mathrm{~h}$ & Induction of apoptosis & [109] \\
\hline
\end{tabular}

\section{Combined Therapy}

A wide variety of chemotherapeutic drugs have been developed for the treatment of different malignancies since the 1940s. Despite the advent of numerous highly efficient cytotoxic agents, the overall rate of cancer-related death is barely reduced during last 70 years. Several major drawbacks have been identified in anticancer chemotherapy, such as non-specific cytotoxicity, which results in bone marrow suppression and other organ toxicity and the development of drug resistance. Indeed, in aggressive malignant neoplasm, a highly variable sensitivity to therapeutics can be observed and some of cell lines can develop resistance to the treatment; the combined effects of bioactive compounds and conventional therapy should be higher compared to a single compound, slowing the development of resistance [110].

An increased drug efflux, alteration of the molecular targets, increased repair of drug-induced DNA damage, activation/suppression of signaling pathways lead to an upregulation of survival molecules and avoidance of apoptosis, the most prominent reasons of tumor cell challenge against chemotherapy [111,112]. The use of anticancer adjuvant therapy with natural bioactive molecules is known to have notable efficacy and protect from vital side effects of chemotherapeutics. For example, TQ pretreatment following Gemcitabine administration synergistically increased apoptosis and inhibited tumor growth both in vitro on human pancreatic cancer cell lines PANC-1, BxPC-3 and AsPC- 1 and in vivo models on PANC-1 cells orthotopic xenograft mice by: (i) suppressing Notch1, NICD and Akt/mTOR/S6 signaling pathways, (ii) decreasing antiapoptotic proteins, such as Bcl-2, Bcl-xL and XIAP, and increasing the activation of proapoptotic molecules, including caspase-3, -9 and Bax and (iii) inhibiting the phosphorylation and nuclear translocation of p65 [113]. Furthermore, an analog of TQ induced apoptosis by downregulating Bcl-2, Bcl-xL, survivin, XIAP, COX-2 combined with Gemcitabine and oxaliplatin in Gemcitabine resistant pancreatic cancer MiaPaCa-2 cells $[67,68]$. Recent studies suggested that TQ with Gemcitabine led to considerable reduction of cell proliferation, induction of apoptosis, necrosis and autophagy in and pancreatic cancer PANC- 1 and Mia PaCa-2 cells via increas- 
ing caspase 3, PARP cleavage, downregulating PKM2, reducing cell viability and regulating two independent microRNA (miR-101 or miR-24-2) [114]. Additionally, TQ significantly increased the antiproliferative activity of gemcitabine by depleting tumor associated resistant stem cell fraction through the induction of apoptosis by 1.5-3.6 folds and exhausted breast cancer associated stem cell $(\mathrm{CD} 44(+) / \mathrm{CD} 24(-) /($ low $)$ clone in gemcitabine-resistant breast MCF-7 and T47D cells by 3.8\%-27.5\%, respectively [115]. It has also been reported that TQ synergistically augmented the anticancer activities of paclitaxel, cisplatin and docetaxel, enhancing apoptosis via JAK-STAT and p53 signaling network in triple-negative breast cancer $[41,116]$. In the case of breast tumor xenograft mice, TQ combined with doxorubicin showed high inhibition of tumor growth through enhancing p-p38 protein expression in tumor tissues, downregulating XIAP, survivin, Bcl-xL and Bcl-2; at the same time it raised catalase, SOD and glutathione levels in liver tissues [35].

Another recent study reported that synergistic effects of TQ and Vitamin D3 or 5-FU could control colon cancer progression in azoxymethane-induced rat model, by arresting the cell cycle in the G1 phase. Specifically, the combined treatment showed a remarkable antitumor effect by dramatically reducing tumor growth and large aberrant crypts loci via Wnt pathway, by decreasing $\beta$-catenin, NF- $k \beta$, COX-2, iNOS, VEGF and HSP-90 and increasing DKK- 1, CDNK-1A, TGF- $\beta 1$, TGF- $\beta /$ RII, smad 4 and GPx in the early stage of CRC $[117,118]$. TQ with cisplatin showed also synergistic effect in lung carcinoma NCIH460, NCI-H146 and LNM35 cells and in mouse xenograft model, by decreasing tumor mass and volume without affecting kidneys or liver [61,119].

In case of leukemia, TQ combined with doxorubicin significantly inhibited cell growth in multidrug-resistant, HL-60 and Jukart cells, by increasing Bax/Bcl-2 mRNA ratio and increasing ROS [120,121]. Moreover, in human platelets TQ and the anticancer drug ABT737 activated protein kinase A (PKA) in a caspase-3-dependent manner, which correlated with platelet inhibition and apoptosis that significantly contributed to the bleeding risk in chemotherapy patients [122].

In bladder cancer, in adult male Wistar rat $N$. sativa oil and TQ exerted protective effect in long term cancer chemotherapy with cisplatin [123], while the combination of platinum drugs cisplatin and oxaliplatin with TQ was effective to overcome drug resistance in ovarian cancer chemotherapy in A2780 cisR cell [124]. In addition, the combined treatment of TQ and cisplatin increased apoptosis through regulating Bcl-2 and Bax genes and exerted antitumoral effects on SK-OV-3 and in ID8-NGL cell line, while in C57BL/ 6 mice, it inhibited NF- $\kappa \beta$ activity and induced DNA damage and proapoptotic effects, reducing cell proliferation $[95,125]$.

Moreover, TQ and Zoledronic combination raised the caspase 3/7 activity in prostate PC-3 cancer cells, but not in DU-145 cell line and showed also significant cytotoxic activity by DNA fragmentation and apoptosis induction [126]; interestingly when TQ was coadministrated with docetaxel, it showed therapeutic effect in DU-145 cells via increased apoptosis through PI3K and ERK signaling pathways modulation [99].

The treatment with TQ and cisplatin or diosgenin decreased cell viability and increased apoptosis, reduced cell growth and proliferation in oral squamous cell carcinoma cell line UMSCC-14C, by upregulating the expression of p53 and caspase 9 and downregulating the expression of Bcl $2[94,127]$.

Finally, TQ showed synergism with radiation in the treatment of head and neck squamous cell carcinoma in SCC25 and CAL27 HNSCC lines due to its antiproliferative and radio sensitizing properties [109].

Table 4 shows the effects of the combined treatment of $N$. sativa and its constituents with anticancer drug and/or other bioactive molecule in various types of cancer. 
Table 4. Combined therapy of Nigella sativa and its constituents with anticancer drug and/or other bioactive molecule in vitro and/or in vivo models of various types of cancer.

\begin{tabular}{|c|c|c|c|c|}
\hline $\begin{array}{c}\text { N. sativa } \\
\text { Extracts/Fraction/ } \\
\text { Component/Analogs }\end{array}$ & Experimental Models & Intervention & Results & References \\
\hline \multicolumn{5}{|l|}{ Pancreatic cancer } \\
\hline \multicolumn{5}{|l|}{ In vitro } \\
\hline $\begin{array}{l}\text { Thymoquinone and } \\
\text { Gemcitabine }\end{array}$ & $\begin{array}{l}\text { PANC-1, AsPC-1 } \\
\text { and BxPC-3 }\end{array}$ & $\begin{array}{c}\text { 0-50 (Thymoquinone) and } \\
0-200 \mu \mathrm{mol} / \mathrm{L} \text { (Gemcitabine) } \\
\text { for } 48 \mathrm{~h}\end{array}$ & $\begin{array}{ll}- & \text { Promotion of apoptosis } \\
- & \text { Inhibition of tumor growth }\end{array}$ & [113] \\
\hline $\begin{array}{l}\text { TQ analogs (TQ-2G, } \\
\text { TQ-4A1 and TQ-5A1) and } \\
\text { Gemcitabine or } \\
\text { Oxaliplatin }\end{array}$ & MiaPaCa-2 & $\begin{array}{c}10 \text { (Thymoquinone analogs) and } \\
0.5 \mu \mathrm{M} \text { (Gemcitabine) or } \\
6.0 \mu \mathrm{g} / \mathrm{mL} \text { (Oxaliplatin) for } 84 \mathrm{~h}\end{array}$ & - $\quad$ Enhancement of apoptosis & [67] \\
\hline $\begin{array}{l}\text { ATQTHB or ATQTFB } \\
\text { analogs and Gemcitabine }\end{array}$ & MiaPaCa-2 cells & $\begin{array}{c}2.5 \text { (analog) and } 0.5 \mu \mathrm{M} \\
\text { (Gemcitabine) } \\
\text { for } 24 \mathrm{~h} \text { and } 72 \mathrm{~h} \\
\end{array}$ & $\begin{array}{l}\text { - Enhancement of cytotoxic } \\
\text { effect }\end{array}$ & [68] \\
\hline $\begin{array}{l}\text { Thymoquinone and } \\
\text { Gemcitabine }\end{array}$ & $\begin{array}{l}\text { MIA PaCa-2 and PANC-1 } \\
\text { cells }\end{array}$ & $25-36 \mu \mathrm{M}$ for $48 \mathrm{~h}$ & $\begin{array}{ll}\text { - } & \text { Inhibition of cancer cell } \\
\text { proliferation } \\
\text { - } & \text { Inhibition of pyruvate kinase } \\
\text { M2 }\end{array}$ & [114] \\
\hline \multicolumn{5}{|l|}{ In vivo } \\
\hline $\begin{array}{l}\text { Thymoquinone and } \\
\text { Gemcitabine }\end{array}$ & $\mathrm{BALB} / \mathrm{c}$ nude mice & $\begin{array}{c}1.0 \mathrm{mg} / \text { day (Thymoquinone) } \\
\text { and } 50 \mathrm{mg} / \mathrm{kg} \\
3 \text { times/week (Gemcitabine), }\end{array}$ & Reduction of tumor weight & [113] \\
\hline \multicolumn{5}{|l|}{ Breast cancer } \\
\hline \multicolumn{5}{|l|}{ In vitro } \\
\hline $\begin{array}{l}\text { Thymoquinone and } \\
\text { Gemcitabine }\end{array}$ & $\begin{array}{l}\text { MCF-7 cells } \\
\text { and T47D }\end{array}$ & $\begin{array}{c}0.01 \text { to } 300 \mu \mathrm{M} \text { for } 24,48 \\
\text { and } 72 \mathrm{~h}\end{array}$ & $\begin{array}{ll}- & \begin{array}{l}\text { Induction of apoptosis and } \\
\text { necrosis }\end{array} \\
- & \text { Increase of autophagic cell } \\
\text { death } \\
- & \begin{array}{l}\text { Depletion of tumor associated } \\
\text { - }\end{array} \\
\text { resistant stem cell fraction }\end{array}$ & [115] \\
\hline $\begin{array}{l}\text { Thymoquinone and } \\
\text { Paclitaxel }\end{array}$ & $4 \mathrm{~T} 1$ cells & $\begin{array}{c}6.25,12.5 \text { and } 25 \\
\text { (Thymoquinone) } \mu \mathrm{M} \\
\text { and } 10 \mu \mathrm{g} / \mathrm{mL} \text { (Paclitaxel) for } \\
24 \mathrm{~h}\end{array}$ & $\begin{array}{ll}- & \text { Inhibition of cancer cell } \\
\text { growth } \\
- & \text { Induction of apoptosis } \\
- & \text { Induction of cytotoxicity }\end{array}$ & [116] \\
\hline $\begin{array}{l}\text { Thymoquinone and } \\
\text { Cisplatin } \\
\text { or Docetaxel }\end{array}$ & MDAMB-468 & $\begin{array}{l}0.5-2 \mu \mathrm{M} \text { Thymoquinone for } \\
24 \mathrm{~h} \text { and } 72 \mathrm{~h}\end{array}$ & $\begin{array}{ll}- & \text { Increase of cytotoxicity } \\
- & \text { Reduction of Akt activation }\end{array}$ & [41] \\
\hline \multicolumn{5}{|l|}{ In vivo } \\
\hline $\begin{array}{l}\text { Thymoquinone and } \\
\text { Doxorubicin }\end{array}$ & $\begin{array}{l}\text { MDA-MB-231 cell } \\
\text { xenograft nude mice }\end{array}$ & $\begin{array}{c}4 \mathrm{mg} / \mathrm{kg} / 6 \text { days/week } \\
\text { (Thymoquinone) and } \\
2.5 \mathrm{mg} / \mathrm{kg} / \text { once } / \text { per week }\end{array}$ & $\begin{array}{ll}- & \text { Antitumor effect } \\
- & \text { Downregulation of } \\
\text { antiapoptotic gene }\end{array}$ & [35] \\
\hline \multicolumn{5}{|l|}{ Colon cancer } \\
\hline \multicolumn{5}{|l|}{ In vivo } \\
\hline $\begin{array}{l}\text { Thymoquinone and } \\
\text { Vitamin D3 }\end{array}$ & azoxymethane treated rat & $\begin{array}{c}35 \mathrm{mg} / \mathrm{kg} / \text { day, three days/week } \\
\text { (Thymoquinone) and } \\
500 \mathrm{IU} / \text { day, } \\
3 \text { days/week (Vitamin D3) }\end{array}$ & $\begin{array}{ll}- & \text { Reduction of tumor growth } \\
- & \begin{array}{l}\text { Decrease of large aberrant } \\
\text { crypts foci }\end{array} \\
-\quad & \text { Increase of antitumorigenesis } \\
\text { biomarker }\end{array}$ & [117] \\
\hline $\begin{array}{l}\text { Thymoquinone and } \\
\text { 5-Fluorouracil }\end{array}$ & $\begin{array}{l}\text { Azoxymethane treated } \\
\text { male Wistar rats }\end{array}$ & $\begin{array}{l}35 \mathrm{mg} / \mathrm{kg} / \mathrm{d} \text { for } 3 \mathrm{~d} / \text { week } \\
\text { (Thymoquinone) } \\
\text { and } 12 \mathrm{mg} / \mathrm{kg} / \mathrm{d} \text { for } 4 \text { days } \\
\text { after } 6 \mathrm{mg} / \mathrm{kg} / \text { day for } \\
5 \text {-Fluorouracil }\end{array}$ & $\begin{array}{l}\text { - } \quad \text { Reduction of tumor growth } \\
\text { Decrease of large aberrant } \\
\text { crypts foci }\end{array}$ & [118] \\
\hline \multicolumn{5}{|l|}{ Lung cancer } \\
\hline In vitro & & & & \\
\hline
\end{tabular}


Table 4. Cont.

\begin{tabular}{|c|c|c|c|c|}
\hline $\begin{array}{c}\text { N. sativa } \\
\text { Extracts/Fraction/ } \\
\text { Component/Analogs }\end{array}$ & Experimental Models & Intervention & Results & References \\
\hline $\begin{array}{l}\text { Thymoquinone and } \\
\text { Cisplatin }\end{array}$ & NCI-H460 and NCI-H146 & $\begin{array}{c}80 \text { and } 100 \mu \mathrm{M} \text { (Thymoquinone) } \\
\text { and } 1.25,2.5 \text { and } 5.0 \text { (Cisplatin) } \\
\text { for } 24,48 \text { and } 72 \mathrm{~h}\end{array}$ & Inhibition of cell proliferation & [61] \\
\hline $\begin{array}{l}\text { Thymoquinone and } \\
\text { Cisplatin }\end{array}$ & LNM35 & $\begin{array}{l}10 \text { and } 50 \mu \mathrm{M} \text { (Thymoquinone) } \\
\text { and } 10 \mu \mathrm{M} \text { (Cisplatin) for } 24 \mathrm{~h}\end{array}$ & Inhibition of cellular viability & [119] \\
\hline \multicolumn{5}{|l|}{ In vivo } \\
\hline $\begin{array}{l}\text { Thymoquinone and } \\
\text { Cisplatin }\end{array}$ & $\begin{array}{l}\text { Severe combined } \\
\text { immunodeficiency mice }\end{array}$ & $\begin{array}{c}5 \text { and } 20 \mathrm{mg} / \mathrm{kg} / 2 \text { days for } \\
3 \text { weeks (Thymoquinone) and } \\
2.5 \text { (Cisplatin) mg/kg/week for } \\
3 \text { weeks }\end{array}$ & $\begin{array}{l}\text { Decrease of tumor volume and } \\
\text { weight }\end{array}$ & [61] \\
\hline \multicolumn{5}{|l|}{ Leukemia } \\
\hline \multicolumn{5}{|l|}{ In vitro } \\
\hline $\begin{array}{l}\text { Thymoquinone and } \\
\text { Doxorubicin }\end{array}$ & HL-60 cells & $5 \mu \mathrm{M}$ for $24 \mathrm{~h}$ & Increase anticancer effect & [120] \\
\hline $\begin{array}{l}\text { Thymoquinone and } \\
\text { Doxorubicin }\end{array}$ & Jurkat cells & $0-30 \mu \mathrm{m}$ for 24,48 and $72 \mathrm{~h}$ & $\begin{array}{ll}- & \text { Inhibition of cell proliferation } \\
\text { - } & \text { Induction of apoptosis }\end{array}$ & [121] \\
\hline \multicolumn{5}{|l|}{ Renal Cancer } \\
\hline \multicolumn{5}{|l|}{ In vivo } \\
\hline N. sativa oil and Cisplatin & male Wistar rats & $\begin{array}{c}2 \mathrm{~mL} / \mathrm{kg} \text { (Thymoquinone) and } \\
3 \mathrm{mg} / \mathrm{kg} \text { (Cisplatin) body wt for } \\
20 \text { days }\end{array}$ & Improvement of nephropathy & \multirow[t]{2}{*}{ [123] } \\
\hline $\begin{array}{l}\text { Thymoquinone and } \\
\text { Cisplatin }\end{array}$ & male Wistar rats & $\begin{array}{l}1.5 \mathrm{mg} / \mathrm{kg} \text { (Thymoquinone) and } \\
3 \mathrm{mg} / \mathrm{kg} \text { body wt (Cisplatin) for } \\
20 \text { days }\end{array}$ & Improvement of nephropathy & \\
\hline \multicolumn{5}{|l|}{ Ovarian cancer } \\
\hline \multicolumn{5}{|l|}{ In vitro } \\
\hline $\begin{array}{l}\text { Thymoquinone and } \\
\text { Cisplatin or Oxaliplatin }\end{array}$ & $\begin{array}{l}\text { A2780 and A2780 cisR } \\
\text { cells }\end{array}$ & $\begin{array}{c}\text { 2.28-36.49 and 1.93- } 30.83 \mu \mathrm{M} \\
\text { (Thymoquinone) } \\
\text { 0.26-4.09 and 1.66-26.52 } \mu \mathrm{M} \\
\text { (Cisplatin), 0.16-2.62 and } \\
\text { 0.59-9.41 } \mu \mathrm{M} \text { (Oxaliplatin) } \\
\text { for } 72 \mathrm{~h}\end{array}$ & Overcome of drug resistance & [124] \\
\hline $\begin{array}{l}\text { Thymoquinone and } \\
\text { Cisplatin }\end{array}$ & SK-OV-3 cells & $\begin{array}{c}10,15,20 \text { and } \\
25 \mu \mathrm{mol} / \mathrm{L} \text { (Thymoquinone) } \\
\text { and } 5,10,15 \text { and } 20 \mu \mathrm{mol} / \mathrm{L} \\
\text { (Cisplatin) } \\
\text { for } 24,48 \text {, and } 72 \mathrm{~h}\end{array}$ & $\begin{array}{ll}\text { - } & \text { Enhancement of apoptosis } \\
\text { - } & \text { Arrest of cell cycle in S phase }\end{array}$ & [125] \\
\hline $\begin{array}{l}\text { Thymoquinone and } \\
\text { Cisplatin }\end{array}$ & Murine ID8-NGL cells & $\begin{array}{c}2.5,5,10,20,25,50 \mu \mathrm{M} \\
\text { (Thymoquinone) and } 0.25,0.5,1 \\
2,2.5,5 \text { (Cisplatin) } \mu \mathrm{M} \text { for } 72 \mathrm{~h}\end{array}$ & $\begin{array}{ll}- & \text { Inhibition of tumor growth } \\
- & \text { Induction of apoptosis } \\
- & \text { Inhibition of cell viability } \\
- & \text { Increase of cytotoxicity }\end{array}$ & [95] \\
\hline \multicolumn{5}{|l|}{ In vivo } \\
\hline $\begin{array}{l}\text { Thymoquinone and } \\
\text { Cisplatin }\end{array}$ & $\begin{array}{l}\text { ID8-NGL treated C57BL/6 } \\
\text { mice }\end{array}$ & $\begin{array}{l}20 \mathrm{mg} / \mathrm{kg} / \text { week for three times } \\
\text { (Thymoquinone), } 2 \mathrm{mg} / \mathrm{kg} \\
\text { /weekly (Cisplatin) for } 30 \text { days }\end{array}$ & $\begin{array}{ll}\text { - } & \text { Decrease of overall tumor } \\
\text { burden }\end{array}$ & [95] \\
\hline \multicolumn{5}{|l|}{ Prostate cancer } \\
\hline \multicolumn{5}{|l|}{ In vitro } \\
\hline $\begin{array}{l}\text { Thymoquinone and } \\
\text { Zoledronic acid }\end{array}$ & PC-3 and DU-145 cells & $\begin{array}{c}55.3 \text { and } 51.0 \mu \mathrm{M} \\
\text { (Thymoquinone) and 95.0, } \\
52.9 \mu \mathrm{M} \text { (Zoledronic acid) for } 24, \\
48 \text { and } 72 \mathrm{~h}\end{array}$ & $\begin{array}{ll}\text { - } & \text { Enhancement of cytotoxicity } \\
\text { - } & \text { Induction of apoptosis }\end{array}$ & [126] \\
\hline $\begin{array}{l}\text { Thymoquinone and } \\
\text { Docetaxel }\end{array}$ & DU-145 cells & $\begin{array}{c}60 \mu \mathrm{M} \text { (Thymoquinone) and } \\
0.1 \text { and } \\
10 \mathrm{nM} \text { (Docetaxel) for } 24,48 \\
\text { and } 72 \mathrm{~h}\end{array}$ & $\begin{array}{ll}\text { - } & \text { Enhancement of cytotoxicity } \\
\text { - } & \text { Induction of apoptosis }\end{array}$ & [99] \\
\hline
\end{tabular}


Table 4. Cont

\begin{tabular}{|c|c|c|c|c|}
\hline $\begin{array}{c}\text { N. sativa } \\
\text { Extracts/Fraction// } \\
\text { Component/Analogs }\end{array}$ & Experimental Models & Intervention & Results & References \\
\hline \multicolumn{5}{|l|}{ Oral cancer } \\
\hline \multicolumn{5}{|l|}{ In vitro } \\
\hline $\begin{array}{l}\text { Thymoquinone and } \\
\text { Diosgenin }\end{array}$ & $\begin{array}{l}\text { Human SCC A431, Hep2 } \\
\text { and RPMI } 2650 \text { cells }\end{array}$ & $\begin{array}{l}10 \mu \mathrm{M} \text { (Thymoquinone) and } \\
20 \mu \mathrm{M} \text { (Diosgenin) for } 48 \mathrm{~h}\end{array}$ & $\begin{array}{ll}\text { - } & \text { Inhibition of cell proliferation } \\
\text { - } & \text { Induction of apoptosis }\end{array}$ & [94] \\
\hline $\begin{array}{l}\text { Thymoquinone and } \\
\text { Cisplatin }\end{array}$ & UMSCC-14C cells & $\begin{array}{l}0.01-100 \mu \mathrm{M} \text { for } \\
24,48 \text { and } 72 \mathrm{~h}\end{array}$ & $\begin{array}{ll}- & \text { Induction of apoptosis } \\
- & \text { Inhibition of cell viability } \\
- & \text { Improvement of } \\
\text { cytotoxic effect }\end{array}$ & [127] \\
\hline \multicolumn{5}{|l|}{ Head and neck cancer } \\
\hline \multicolumn{5}{|l|}{ In vitro } \\
\hline $\begin{array}{l}\text { Thymoquinone and } \\
\text { radiation }\end{array}$ & $\begin{array}{l}\text { SCC25 and CAL27 } \\
\text { HNSCC cell lines }\end{array}$ & $\begin{array}{c}0-80 \mu \mathrm{M} \text { (Thymoquinone) and } \\
2 \text { Gy } / \mathrm{min} \\
\text { for } 72 \mathrm{~h}\end{array}$ & Reduction of survival & [109] \\
\hline
\end{tabular}

\section{Clinical Studies}

To the best of our knowledge, few clinical studies have been performed with $N$. sativa [128-130]. In children (2-18 years) with acute lymphoblastic leukemia N. saliva seed significantly improved the treatment outcome: the combination of TQ with other cytotoxic drugs, including L-asparaginase, administered at dose $40 \mathrm{mg} / \mathrm{kg} 2$ times orally for 6 months led to a remission rate of $92 \%$; at the same time TQ increased survival rate and exerted non-toxic effects in healthy subjects [128]. Furthermore, in one randomized phase 2 parallel-grouped clinical trial TQ reduced lesion in patients (aged 18-75 years) suffering from oral potential premalignant lesions at dose 100/200 $\mathrm{mg}$ for 2 years (ClinicalTrials.gov Identifier: NCT03208790) [129]. In addition, in an Arabian Phase I trial TQ was found safe and well-tolerated in patients up to $10 \mathrm{mg} / \mathrm{kg} /$ day, but at this dosage, there was no significant anticancer activity found [130].

\section{Conclusions and Future Perspectives}

Despite the efforts, cancer still remains undefeated in the history of mankind with an annual death rate of over a million. Natural products like N. sativa have contributed to the discovery of new anticancer strategies and its major constituents such as TQ are promising candidates to remarkably combat cancer progression. Their effectiveness to prevent different processes related to cancer, such as proliferation, migration and invasion, angiogenesis and metastasis were here described and reported (Table 3). Moreover, we also showed that TQ enhances the anticancer effect of chemotherapeutic agents and radiotherapy in combined therapy. Results accomplished from such studies may open a new route in the field of alternative medicines for preventing various types of cancer. Hence, further investigation is required to study the anticancer effect of $N$. sativa and its constituents in suitable combinations with existing chemotherapeutic agents for effective treatment of many cancers. Moreover, it should be considered the specific cellular and molecular targets of various constituents of $N$. sativa. It is known that $N$. sativa can act both as a ROS inducer at relatively high concentration and as an antioxidant at low concentration. For well understanding these differential cellular effects, further in vivo and in silico studies should be performed at both the genomic and proteomic level, especially considering that the data obtained in vitro are generally difficult to translate in in vivo conditions as recently reported [131].

Therefore, more studies are recommended to improve the pharmacodynamics and bioavailability of $N$. sativa in order to highlight its potency and poor bioavailability. These issues can be resolved by synthesizing various analogs of $N$. sativa and its constituents and formulating those into different delivery systems in adequate preclinical and clinical 
studies, where N. sativa or its derivatives can potentiate the antitumorigenic potential of various conventional and well-established anticancer agents.

Author Contributions: Conceptualization, F.G. and T.Y.F.-H.; software, L.R. and D.Q.; data curation, S.G.V.; writing — original draft preparation, F.G. and J.A.; writing—review and editing, J.M.A.-S. and D.C.; visualization, E.G.V. and K.T.P.; supervision, M.B. and D.C.; project administration, M.B. All authors have read and agreed to the published version of the manuscript.

Funding: This research received no external funding.

Acknowledgments: Tamara Y. Forbes-Hernández is supported by a "Juan de la Cierva-Formación" post-doctoral contract.

Conflicts of Interest: The authors declare no conflict of interest

\section{References}

1. GBD 2015 Risk Factors Collaborators. Global, regional, and national comparative risk assessment of 79 behavioural, environmental and occupational, and metabolic risks or clusters of risks, 1990-2015: A systematic analysis for the Global Burden of Disease Study 2015. Lancet 2016, 388, 1659-1724. [CrossRef]

2. Khan, A.; Chen, H.C.; Tania, M.; Zhang, D.Z. Anticancer activities of Nigella sativa (black cumin). Afr. J. Tradit. Complement Altern. Med. 2011, 8, 226-232. [CrossRef] [PubMed]

3. You, J.S.; Jones, P.A. Cancer genetics and epigenetics: Two sides of the same coin? Cancer Cell 2012, 22, 9-20. [CrossRef]

4. Das, T.; Sa, G.; Saha, B.; Das, K. Multifocal signal modulation therapy of cancer: Ancient weapon, modern targets. Mol. Cell Biochem. 2010, 336, 85-95. [CrossRef] [PubMed]

5. Majdalawieh, A.F.; Fayyad, M.W.; Nasrallah, G.K. Anti-cancer properties and mechanisms of action of thymoquinone, the major active ingredient of Nigella sativa. Crit. Rev. Food Sci. Nutr. 2017, 57, 3911-3928. [CrossRef]

6. Bose, S.; Panda, A.K.; Mukherjee, S.; Sa, G. Curcumin and tumor immune-editing: Resurrecting the immune system. Cell Div. 2015, 10, 6. [CrossRef]

7. Hossain, D.M.; Bhattacharyya, S.; Das, T.; Sa, G. Curcumin: The multi-targeted therapy for cancer regression. Front. Biosci. Schol. Ed. 2012, 4, 335-355. [CrossRef] [PubMed]

8. Afrin, S.; Giampieri, F.; Gasparrini, M.; Forbes-Hernández, T.Y.; Cianciosi, D.; Reboredo-Rodriguez, P.; Zhang, J.; Manna, P.P.; Daglia, M.; Atanasov, A.G.; et al. Dietary phytochemicals in colorectal cancer prevention and treatment: A focus on the molecular mechanisms involved. Biotechnol. Adv. 2018, 38, 107322. [CrossRef] [PubMed]

9. Danaei, G.H.; Memar, B.; Ataee, R.; Karami, M. Protective effect of thymoquinone, the main component of Nigella sativa, against diazinon cardio-toxicity in rats. Drug Chem. Toxicol. 2018, 42, 585-591. [CrossRef]

10. Tabassum, H.; Ahmad, A.; Ahmad, I.Z. Nigella sativa L. and its bioactive constituents as hepato protectant: A review. Curr. Pharm. Biotechnol. 2018, 19, 43-67. [CrossRef]

11. Imran, M.; Rauf, A.; Khan, I.A.; Shahbaz, M.; Qaisrani, T.B.; Fatmawati, S.; Abu-Izneid, T.; Imran, A.; Rahman, K.U.; Gondal, T.A. Thymoquinone: A novel strategy to combat cancer: A review. Biomed. Pharmacother. 2018, 106, 390-402. [CrossRef] [PubMed]

12. Greenish, H.G. Contribution to the chemistry of Nigella sativa. Pharmac. J. Trans. 1880, 10, 909-911.

13. Al-Jassir, M.S. Chemical composition and microflora of black cumin (Nigella sativa L.) seeds growing in Saudi Arabia. Food Chem. 1992, 45, 239-242. [CrossRef]

14. Ustun, G.; Kent, L.; Cekin, N.; Civelekoglu, H. Investigation of the technological properties of Nigella sativa (Black Cumin) seed oil. J. Am. Oil Chem. 1990, 67, 958-960. [CrossRef]

15. Dandik, L.; Aksoy, H.A. The kinetics of hydrolysis of Nigella sativa (Black cumin) seed oil catalyzed by native lipase in ground seed. J. Am. Oil Chem. Soc. 1992, 69, 1239-1241. [CrossRef]

16. Ali, B.H.; Blunden, G. Pharmacological and toxicological properties of Nigella sativa. Phytother. Res. 2003, 17, 299-305. [CrossRef]

17. Abdel-Aal, E.S.; Attia, R.S. Characterization of black cumin (Nigella sativa) seeds 1-chemical composition and lipids. Alex. Sci. Exch. 1993, 14, 467.

18. Nergiz, C.; Ötleş, S. Chemical composition of Nigella sativa L. seeds. Food Chem. 1993, 48, 259-261. [CrossRef]

19. Dandik, L.; Aksoy, H.A. Applications of Nigella sativa seed lipase in oleochemical reactions. Enz. Microb. Technol. 1996, 19, $277-281$. [CrossRef]

20. El-Dhaw, Z.Y.; Abdel-Munaem, N.M. Chemical and biological values of black cumin seeds. J. Agric. Sci. Mansoura Univ. 1996, 21, 4149-4159.

21. Takruri, H.R.H.; Dameh, M.A.F. Study of nutritional value of black cumin seeds (Nigella sativa L.). J. Sci. Food Agric. 1998, 76, 404-410. [CrossRef]

22. Üstün, G.; Turkay, S.; Karaali, A. Nigella sativa seeds: A potential source for oil and oleochemicals. In Proceedings of the World Conference on Oil Seed and Edible Oil Processing, Istanbul, Turkey, 6-10 October 1996; AOCS Press: Champaign, IL, USA, 1998; Volume 2, pp. 155-160. 
23. Jadayil, S.A.; Tukan, S.K.; Takruri, H.R. Bioavailability of iron from four different local food plants in Jordan. Plant Foods Hum. Nutr. 1999, 54, 285-294. [CrossRef] [PubMed]

24. Atta, M.B. Some characteristics of nigella (Nigella sativa L.) seed cultivated in Egypt and its lipid profile. Food Chem. 2003, 83, 63-68. [CrossRef]

25. Nickavar, B.; Mojab, F.; Javidnia, K.; Amoli, M.A.R. Chemical composition of the fixed and volatile oils of Nigella sativa L. from Iran. Z. Naturforsch. C J. Biosci. 2003, 58, 629-631. [CrossRef]

26. Ramadan, M.F.; Morsel, J.T. Analysis of glycolipids from black cumin (Nigella sativa L.), coriander (Coriandrum sativum L.) and niger (Guizotia abyssinica Cass.) oilseeds. Food. Chem. 2003, 80, 197-204. [CrossRef]

27. Ramadan, M.F.; Morsel, J.T. Oxidative stability of black cumin (Nigella sativa L.), coriander (Coriandrum sativum L.) and niger (Guizotia abyssinica Cass.) crude seed oils upon stripping. Eur. J. Lipid Sci. Technol. 2004, 106, 35-43. [CrossRef]

28. Al-Saleh, I.A.; Billedo, G.; El-Doush, I.I. Levels of selenium, DLa-tocopherol, DL-g-tocopherol, all-trans-retinol, thymoquinone and thymol in different brands of Nigella sativa seeds. J. Food Comp. Anal. 2006, 19, 167-175. [CrossRef]

29. Ashraf, M.; Ali, Q.; Iqbal, Z. Effect of nitrogen application rate on the content and composition of oil, essential oil and minerals in black cumin (Nigella sativa L.) seeds. J. Sci. Food Agric. 2006, 86, 871-876. [CrossRef]

30. Cheikh-Rouhou, S.; Besbes, S.; Hentati, B.; Blecker, C.; Deroanne, C.; Attia, H. Nigella sativa L.: Chemical composition and physicochemical characteristics of lipid fraction. Food Chem. 2007, 101, 673-681. [CrossRef]

31. Ghosheh, O.A.; Houdi, A.A.; Crooks, P.A. High performance liquid chromatographic analysis of the pharmacologically active quinones and related compounds in the oil of the black seed (Nigella sativa L.). J. Pharm. Biomed. Anal. 1999, 19, 757-762. [CrossRef]

32. Malik, S.; Cun-Heng, H.; Clardy, J. Isolation and structure determination of nigellicine, a novel alkaloid from the seeds of nigella sativa. Tetrahedron Lett. 1985, 26, 2759-2762.

33. Butt, M.S.; Sultan, M.T. Nigella sativa: Reduces the risk of various maladies. Crit. Rev. Food Sci. Nut. 2010, 50, 654-665. [CrossRef] [PubMed]

34. World Health Organization. Global Health Estimates; World Health Organization: Geneva, Switzerland, 2013; Available online: http:/ / www.who.int/healthinfo/global_burden_disease/en/ (accessed on 14 July 2020).

35. Woo, C.C.; Hsu, A.; Kumar, A.P.; Sethi, G.; Tan, K.H.B. Thymoquinone inhibits tumor growth and induces apoptosis in a breast cancer xenograft mouse model: The role of p38 MAPK and ROS. PLoS ONE 2013, 8, e75356. [CrossRef]

36. Rajput, S.; Kumar, B.P.; Dey, K.K.; Pal, I.; Parekh, A.; Mandal, M. Molecular targeting of Akt by thymoquinone promotes G1 arrest through translation inhibition of cyclin D1 and induces apoptosis in breast cancer cells. Life Sci. 2013, 93, 783-790.-790. [CrossRef] [PubMed]

37. Khurshid, Y.; Syed, B.; Simjee, S.U.; Beg, O.; Ahmed, A. Antiproliferative and apoptotic effects of proteins from black seeds (Nigella sativa) on human breast MCF-7 cancer cell line. BMC Complement. Med. Ther. 2020, 20, 1-11. [CrossRef]

38. Woo, C.C.; Loo, S.Y.; Gee, V.; Yap, C.W.; Sethi, G.; Kumar, A.P.; Tan, K.H.B. Anticancer activity of thymoquinone in breast cancer cells: Possible involvement of PPAR- $\gamma$ pathway. Biochem. Pharmacol. 2011, 82, 464-475. [CrossRef]

39. Shanmugam, M.K.; Ahn, K.S.; Hsu, A.; Woo, C.C.; Yuan, Y.; Tan, K.H.B.; Chinnathambi, A.; Alahmadi, T.A.; Alharbi, S.A.; Koh, A.P.F.; et al. Thymoquinone inhibits bone metastasis of breast cancer cells through abrogation of the CXCR4 signaling axis. Front. Pharmacol. 2018, 9, 1294. [CrossRef] [PubMed]

40. Khan, M.A.; Tania, M.; Wei, C.; Mei, Z.; Fu, S.; Cheng, J.; Xu, J.; Fu, J. Thymoquinone inhibits cancer metastasis by downregulating TWIST1 expression to reduce epithelial to mesenchymal transition. Oncotarget 2015, 6, 19580. [CrossRef]

41. Sutton, K.M.; Greenshields, A.L.; Hoskin, D.W. Thymoquinone, a bioactive component of black caraway seeds, causes G1 phase cell cycle arrest and apoptosis in triple-negative breast cancer cells with mutant p53. Nutr. Cancer 2014, 66, 408-418. [CrossRef]

42. Arafa, E.S.A.; Zhu, Q.; Shah, Z.I.; Wani, G.; Barakat, B.M.; Racoma, I.; El-Mahdy, M.A.; Wani, A.A. Thymoquinone up-regulates PTEN expression and induces apoptosis in doxorubicin-resistant human breast cancer cells. Mutat. Res. 2011, 706, 28-35. [CrossRef]

43. El-Aziz, M.A.A.; Hassan, H.A.; Mohamed, M.H.; Meki, A.R.M.; Abdel-Ghaffar, S.K.; Hussein, M.R. The biochemical and morphological alterations following administration of melatonin, retinoic acid and Nigella sativa in mammary carcinoma: An animal model. Int. J. Exp. Pathol. 2005, 86, 383-396. [CrossRef] [PubMed]

44. Rooney, S.; Ryan, M.F. Effects of alpha-hederin and thymoquinone, constituents of Nigella sativa, on human cancer cell lines. Anticancer Res. 2005, 25, 2199-2204. [PubMed]

45. Chen, M.-C.; Lee, N.-H.; Hsu, H.-H.; Ho, T.J.; Tu, C.C.; Hsieh, D.J.; Lin, Y.M.; Chen, L.M.; Kuo, W.W.; Huang, C.Y. Thymoquinone induces caspase-independent, autophagic cell death in CPT-11-resistant lovo colon cancer via mitochondrial dysfunction and activation of JNK and p38. J. Agric. Food Chem. 2015, 63, 1540-1546. [CrossRef] [PubMed]

46. Chen, M.C.; Lee, N.H.; Hsu, H.H.; Ho, T.J.; Tu, C.C.; Chen, R.J.; Yueh-Min Lin, Y.M.; Viswanadha, V.P.; Kuo, W.W.; Huang, C.Y. Inhibition of NF- $\mathrm{KB}$ and metastasis in irinotecan (CPT-11)-resistant LoVo colon cancer cells by thymoquinone via JNK and p38. Environ. Toxicol. 2017, 32, 669-678. [CrossRef]

47. El-Najjar, N.; Chatila, M.; Moukadem, H.; Vuorela, H.; Ocker, M.; Gandesiri, M.; Schneider-Stock, R.; Gali-Muhtasib, H. Reactive oxygen species mediate thymoquinone-induced apoptosis and activate ERK and JNK signaling. Apoptosis 2010, 15, 183-195. [CrossRef] 
48. Hsu, H.H.; Chen, M.C.; Day, C.H.; Lin, Y.M.; Li, S.Y.; Tu, C.C.; Padma, V.V.; Shih, H.N.; Kuo, W.W.; Huang, C.Y. Thymoquinone suppresses migration of LoVo human colon cancer cells by reducing prostaglandin E2 induced COX-2 activation. World J. Gastroenterol. 2017, 23, 71171-71179. [CrossRef]

49. Kundu, J.; Choi, B.Y.; Jeong, C.H.; Kundu, J.K.; Chun, K.S. Thymoquinone induces apoptosis in human colon cancer HCT116 cells through inactivation of STAT3 by blocking JAK2-and Src-mediated phosphorylation of EGF receptor tyrosine kinase. Oncol. Rep. 2014, 32, 821-828. [CrossRef]

50. Al-Johar, D.; Shinwari, N.; Arif, J.; Al-Sanea, N.; Jabbar, A.A.; El-Sayed, R.A.; Mashhour, A.; Billedo, G.; El-Doush, I.; Al-Saleh, I. Role of Nigella sativa and a number of its antioxidant constituents towards azoxymethane-induced genotoxic effects and colon cancer in rats. Phytother. Res. 2008, 22, 1311-1323. [CrossRef]

51. Asfour, W.; Almadi, S.; Haffar, L. Thymoquinone suppresses cellular proliferation, inhibits VEGF production and obstructs tumor progression and invasion in the rat model of DMH-induced colon carcinogenesis. Pharm. Pharmacol. 2013, 4, 7-17. [CrossRef]

52. Hassan, M.I.; Mabrouk, G.M.; Shehata, H.H.; Aboelhussein, M.M. Antineoplastic effects of bee honey and Nigella sativa on hepatocellular carcinoma cells. Integr. Cancer Ther. 2012, 11, 354-363. [CrossRef]

53. Ashour, A.E.; Abd-Allah, A.R.; Korashy, H.M.; Attia, S.M.; Alzahrani, A.Z.; Saquib, Q.; Bakheet, S.A.; Abdel-Hamied, H.E.; Jamal, S.; Rishi, A.K. Thymoquinone suppression of the human hepatocellular carcinoma cell growth involves inhibition of IL-8 expression, elevated levels of TRAIL receptors, oxidative stress and apoptosis. Mol. Cell. Biochem. 2014, 389, 85-98. [CrossRef]

54. ElKhoely, A.; Hafez, H.F.; Ashmawy, A.M.; Badary, O.; Abdelaziz, A.; Mostafa, A.; Shouman, S.A. Chemopreventive and therapeutic potentials of thymoquinone in HepG2 cells: Mechanistic perspectives. J. Nat. Med. 2015, 69, 313-323. [CrossRef]

55. Palabiyik, S.S.; Karakus, E.; Halici, Z.; Cadirci, E.; Bayir, Y.; Ayaz, G.; Cinar, I. The protective effects of carvacrol and thymol against paracetamol-induced toxicity on human hepatocellular carcinoma cell lines (HepG2). Hum. Exp. Toxicol. 2016, 35, 1252-1263. [CrossRef]

56. Shahin, Y.R.; Elguindy, N.M.; Abdel Bary, A.; Balbaa, M. The protective mechanism of Nigella sativa against diethylnitrosamineinduced hepatocellular carcinoma through its antioxidant effect and EGFR/ERK1/2 signaling. Environ. Toxicol. Chem. 2018, 33, 885-898. [CrossRef]

57. Sayed-Ahmed, M.M.; Aleisa, A.M.; Al-Rejaie, S.S.; Al-Yahya, A.A.; Al-Shabanah, O.A.; Hafez, M.M.; Nagi, M.N. Thymoquinone attenuates diethylnitrosamine induction of hepatic carcinogenesis through antioxidant signaling. Oxid. Med. Cell. Longev. 2010, 3, 254-261. [CrossRef] [PubMed]

58. Fathy, M.; Nikaido, T. In vivo attenuation of angiogenesis in hepatocellular carcinoma by Nigella sativa. Turk. J. Med. Sci. 2018, 48, 178-186. [CrossRef] [PubMed]

59. Raghunandhakumar, S.; Paramasivam, A.; Senthilraja, S.; Naveenkumar, C.; Asokkumar, S.; Binuclara, J.; Jagan, S.; Anandakumar, P.; Devaki, T. Thymoquinone inhibits cell proliferation through regulation of G1/S phase cell cycle transition in N-nitrosodiethylamine-induced experimental rat hepatocellular carcinoma. Toxicol. Lett. 2013, 223, 60-72. [CrossRef] [PubMed]

60. Samarghandian, S.; Azimi-Nezhad, M.; Farkhondeh, T. Thymoquinone-induced antitumor and apoptosis in human lung adenocarcinoma cells. J. Cell Physiol. 2019, 234, 10421-10431. [CrossRef]

61. Jafri, S.H.; Glass, J.; Shi, R.; Zhang, S.; Prince, M.; Kleiner-Hancock, H. Thymoquinone and cisplatin as a therapeutic combination in lung cancer: In vitro and in vivo. J. Exp. Clin. Cancer Res. 2010, 29, 87. [CrossRef] [PubMed]

62. Yang, J.; Kuang, X.R.; Lv, P.T.; Yan, X.X. Thymoquinone inhibits proliferation and invasion of human nonsmall-cell lung cancer cells via ERK pathway. Tumor Biol. 2015, 36, 259-269. [CrossRef] [PubMed]

63. Acharya, B.R.; Chatterjee, A.; Ganguli, A.; Bhattacharya, S.; Chakrabarti, G. Thymoquinone inhibits microtubule polymerization by tubulin binding and causes mitotic arrest following apoptosis in A549 cells. Biochimie 2014, 97, 78-91. [CrossRef]

64. Zhu, N.; Zhao, X.; Xiang, Y.; Ye, S.; Huang, J.; Hu, W.; Lv, L.; Zeng, C. Thymoquinone attenuates monocrotaline-induced pulmonary artery hypertension via inhibiting pulmonary arterial remodeling in rats. Int. J. Cardiol. 2016, 221, 587-596. [CrossRef]

65. Torres, M.P.; Ponnusamy, M.P.; Chakraborty, S.; Smith, L.M.; Das, S.; Arafat, H.A.; Batra, S.K. Effects of thymoquinone in the expression of mucin 4 in pancreatic cancer cells: Implications for the development of novel cancer therapies. Mol. Cancer Ther. 2010, 9, 1419-1431. [CrossRef] [PubMed]

66. Chehl, N.; Chipitsynam, G.; Gongm, Q.; Yeom, C.J.; Arafatm, H.A. Anti-inflammatory effects of the Nigella sativa seed extract, thymoquinone, in pancreatic cancer cells. HPB 2009, 11, 373-381. [CrossRef]

67. Banerjee, S.; Azmi, A.S.; Padhye, S.; Singh, M.W.; Baruah, J.B.; Philip, P.A.; Sarkar, F.H.; Mohammad, R.M. Structure-activity studies on therapeutic potential of Thymoquinone analogs in pancreatic cancer. Pharm. Res. 2010, 27, 1146-1158. [CrossRef]

68. Yusufi, M.; Banerjee, S.; Mohammad, M.; Khatal, S.; Swamy, K.V.; Khan, E.M.; Aboukameel, A.; Sarkar, F.H.; Padhye, S. Synthesis, characterization and anti-tumor activity of novel thymoquinone analogs against pancreatic cancer. Bioorg. Med. Chem. Lett. 2013, 23, 3101-3104. [CrossRef]

69. Shafi, G.; Munshi, A.; Hasan, T.N.; Alshatwi, A.A.; Jyothy, A.; Lei, D.K. Induction of apoptosis in HeLa cells by chloroform fraction of seed extracts of Nigella sativa. Cancer Cell Int. 2009, 9, 29. [CrossRef]

70. Sakalar, C.; Yuruk, M.; Kaya, T.; Aytekin, M.; Kuk, S.; Canatan, H. Pronounced transcriptional regulation of apoptotic and TNF-NF-kappa-B signaling genes during the course of thymoquinone mediated apoptosis in HeLa cells. Mol. Cell. Biochem. 2013, 383, 243-251. [CrossRef] [PubMed]

71. Brewer, J.; Benghuzzi, H.; Tucci, M. Effects of thymoquinone, lycopene, and selenomethione in the presence of estrogen on the viability of SiHa cells in vitro. Biomed. Sci. Instrum. 2006, 42, 37-41. 
72. Ng, W.K.; Yazan, L.S.; Ismail, M. Thymoquinone from Nigella sativa was more potent than cisplatin in eliminating of SiHa cells via apoptosis with down-regulation of Bcl-2 protein. Toxicol. In Vitro 2011, 25, 1392-1398. [CrossRef] [PubMed]

73. Ichwan, S.J.; Al-Ani, I.M.; Bilal, H.G.; Suriyah, W.H.; Taher, M.; Ikeda, M.A. Apoptotic activities of thymoquinone, an active ingredient of black seed (Nigella sativa), in cervical cancer cell lines. Chin. J. Physiol. 2014, 57, 249-255. [CrossRef] [PubMed]

74. Li, J.; Khan, M.; Wei, C.; Cheng, J.; Chen, H.; Yang, L.; Ijaz, I.; Fu, J. Thymoquinone inhibits the migration and invasive characteristics of cervical cancer cells $\mathrm{SiHa}$ and CaSki in vitro by targeting epithelial to mesenchymal transition associated transcription factors Twist1 and Zeb1. Molecules 2017, 22, 2105. [CrossRef]

75. Reindl, W.; Yuan, J.; Krämer, A.; Strebhardt, K.; Berg, T. Inhibition of polo-like kinase 1 by blocking polo-box domain-dependent protein-protein interactions. Chem. Biol. 2008, 15, 459-466. [CrossRef]

76. Abusnina, A.; Alhosin, M.; Keravis, T.; Muller, C.D.; Fuhrmann, G.; Bronner, C.; Lugnier, C. Down-regulation of cyclic nucleotide phosphodiesterase PDE1A is the key event of p73 and UHRF1 deregulation in thymoquinone-induced acute lymphoblastic leukemia cell apoptosis. Cell Signal. 2011, 23, 152-160. [CrossRef] [PubMed]

77. Salim, L.; Mohan, S.; Othman, R.; Abdelwahab, S.; Kamalidehghan, B.; Sheikh, B.; Ibrahim, M. Thymoquinone induces mitochondria-mediated apoptosis in acute lymphoblastic leukaemia in vitro. Molecules 2013, 18, 11219-11240. [CrossRef]

78. Alhosin, M.; Ibrahim, A.; Boukhari, A.; Sharif, T.; Gies, J.P.; Auger, C.; Schini-Kerth, V.B. Anti-neoplastic agent thymoquinone induces degradation of $\alpha$ and $\beta$ tubulin proteins in human cancer cells without affecting their level in normal human fibroblasts. Investig. New Drugs. 2012, 30, 1813-1819. [CrossRef]

79. Pang, J.; Shen, N.; Yan, F.; Zhao, N.; Dou, L.; Wu, L.C.; Seiler, C.L.; Yu, L.; Yang, K.; Bachanova, V.; et al. Thymoquinone exerts potent growth-suppressive activity on leukemia through DNA hypermethylation reversal in leukemia cells. Oncotarget 2017, 8, 34453.

80. Salim, L.Z.A.; Othman, R.; Abdulla, M.A.; Al-Jashamy, K.; Ali, H.M.; Hassandarvish, P.; Dehghan, F.; Ibrahim, M.Y.; Omer, F.A.; Mohan, S. Thymoquinone inhibits murine leukemia WEHI-3 cells in vivo and in vitro. PLoS ONE 2014, 9, e115340. [CrossRef] [PubMed]

81. Qadi, S.A.; Hassan, M.A.; Sheikh, R.A.; Baothman, O.A.; Zamzami, M.A.; Choudhry, H.; Al-Malki, A.L.; Albukhari, A.; Alhosin, M. Thymoquinone-Induced Reactivation of Tumor Suppressor Genes in Cancer Cells Involves Epigenetic Mechanisms. Epigenet. Insights 2019, 12, 2516865719839011. [CrossRef]

82. Badr, G.; Lefevre, E.A.; Mohany, M. Thymoquinone inhibits the CXCL12-induced chemotaxis of multiple myeloma cells and increases their susceptibility to Fas-mediated apoptosis. PLoS ONE 2011, 6, e23741. [CrossRef] [PubMed]

83. Effenberger, K.; Breyer, S.; Schobert, R. Terpene conjugates of the Nigella sativa seed-oil constituent thymoquinone with enhanced efficacy in cancer cells. Chem. Biodivers. 2010, 7, 129-139. [CrossRef]

84. Park, E.J.; Chauhan, A.K.; Min, K.J.; Park, D.C.; Kwon, T.K. Thymoquinone induces apoptosis through downregulation of c-FLIP and Bcl-2 in renal carcinoma Caki cells. Oncol. Rep. 2016, 36, 2261-2267. [CrossRef] [PubMed]

85. Lee, Y.M.; Kim, G.H.; Park, E.J.; Oh, T.I.; Lee, S.; Kan, S.Y.; Kang, H.; Kim, B.M.; Kim, J.H.; Lim, J.H. Thymoquinone Selectively Kills Hypoxic Renal Cancer Cells by Suppressing HIF-1 $\alpha$-Mediated Glycolysis. Int. J. Mol. Sci. 2019, 20, 1092. [CrossRef]

86. Chae, I.G.; Song, N.Y.; Kim, D.H.; Lee, M.Y.; Park, J.M.; Chun, K.S. Thymoquinone induces apoptosis of human renal carcinoma Caki-1 cells by inhibiting JAK2/STAT3 through pro-oxidant effect. Food Chem. Toxicol. 2020, 139, 111253. [CrossRef] [PubMed]

87. Kou, B.; Kou, Q.; Ma, B.; Zhang, J.; Sun, B.; Yang, Y.; Li, J.; Zhou, J.; Liu, W. Thymoquinone inhibits metastatic phenotype and epithelial mesenchymal transition in renal cell carcinoma by regulating the LKB1/AMPK signaling pathway. Oncol. Rep. 2018, 40, 1443-1450. [CrossRef]

88. Shahraki, S.; Khajavirad, A.; Shafei, M.N.; Mahmoudi, M.; Tabasi, N.S. Effect of total hydroalcholic extract of Nigella sativa and its n-hexane and ethyl acetate fractions on ACHN and GP-293 cell lines. J. Tradit. Complement. Med. 2016, 6, 89-96. [CrossRef] [PubMed]

89. Iskender, B.; Izgi, K.; Hizar, E.; Jauch, J.; Arslanhan, A.; Yuksek, E.H.; Canatan, H. Inhibition of epithelial-mesenchymal transition in bladder cancer cells via modulation of mTOR signalling. Tumour Biol. 2016, 37, 8281-8291. [CrossRef] [PubMed]

90. Zhang, M.; Du, H.; Wang, L.; Yue, Y.; Zhang, P.; Huang, Z.; Lv, W.; Ma, J.; Shao, Q.; Ma, M.; et al. Thymoquinone suppresses invasion and metastasis in bladder cancer cells by reversing EMT through the Wnt/ $\beta$-catenin signaling pathway. Chem. Biol. Interact. 2020, 320, 109022. [CrossRef]

91. Zhang, M.; Du, H.; Huang, Z.; Zhang, P.; Yue, Y.; Wang, W.; Liu, W.; Zeng, J.; Ma, J.; Chen, G.; et al. Thymoquinone induces apoptosis in bladder cancer cell via endoplasmic reticulum stress-dependent mitochondrial pathway. Chem. Biol. Interact. 2018, 292, 65-75. [CrossRef]

92. Sang, Y.; Deng, Y. Current insights into the epigenetic mechanisms of skin cancer. Dermatol. Ther. 2019, 32, e12964. [CrossRef]

93. Iqbal, J.; Abbasi, B.A.; Ahmad, R.; Batool, R.; Mahmood, T.; Ali, B.; Khalil, A.T.; Kanwal, S.; Shaha, S.A.; Alam, M.M.; et al. Potential phytochemicals in the fight against skin cancer: Current landscape and future perspectives. Biomed. Pharmacother. 2019, 109, 1381-1393. [CrossRef]

94. Das, S.; Dey, K.K.; Dey, G.; Pal, I.; Majumder, A.; Maiti Choudhury, S.; Mandal, M. Antineoplastic and apoptotic potential of traditional medicines thymoquinone and diosgenin in squamous cell carcinoma. PLoS ONE 2012, 7, e46641. [CrossRef] [PubMed]

95. Wilson, A.J.; Saskowski, J.; Barham, W.; Yull, F.; Khabele, D. Thymoquinone enhances cisplatin-response through direct tumor effects in a syngeneic mouse model of ovarian cancer. J. Ovarian Res. 2015, 8, 46. [CrossRef] [PubMed] 
96. Johnson-Ajinwo, O.R.; Ullah, I.; Mbye, H.; Richardson, A.; Horrocks, P.; Li, W.W. The synthesis and evaluation of thymoquinone analogues as anti-ovarian cancer and antimalarial agents. Bioorg. Med. Chem. Lett. 2018, 28, 1219-1222. [CrossRef] [PubMed]

97. Wilson, A.J.; Barham, W.; Saskowski, J.; Tikhomirov, O.; Chen, L.; Lee, H.J.; Yull, F.; Khabele, D. Tracking NF-k $\beta$ activity in tumor cells during ovarian cancer progression in a syngeneic mouse model. J. Ovarian Res. 2013, 6, 63. [CrossRef]

98. Kou, B.; Liu, W.5; Zhao, W.; Duan, P.; Yang, Y.; Yi, Q.; Guo, F.; Li, J.; Zhou, J.; Kou, Q. Thymoquinone inhibits epithelialmesenchymal transition in prostate cancer cells by negatively regulating the TGF- $\beta / \mathrm{Smad} 2 / 3$ signaling pathway. Oncol. Rep. 2017, 38, 3592-3598. [CrossRef]

99. Dirican, A.; Atmaca, H.; Bozkurt, E.; Erten, C.; Karaca, B.; Uslu, R. Novel combination of docetaxel and thymoquinone induces synergistic cytotoxicity and apoptosis in DU-145 human prostate cancer cells by modulating PI3K-AKT pathway. Clin. Transl. Oncol. 2015, 17, 145-151. [CrossRef]

100. Kus, G.; Ozkurt, M.; Kabadere, S.; Erkasap, N.; Goger, G.; Demirci, F. Antiproliferative and antiapoptotic effect of thymoquinone on cancer cells in vitro. Bratisl. Lek. Listy 2018, 119, 312-316. [CrossRef]

101. Koka, P.S.; Mondal, D.; Schultz, M.; Abdel-Mageed, A.B.; Agrawal, K.C. Studies on molecular mechanisms of growth inhibitory effects of thymoquinone against prostate cancer cells: Role of reactive oxygen species. Exp. Biol. Med. 2010, 235, 751-760. [CrossRef]

102. Zubair, H.; Khan, H.Y.; Sohail, A.; Azim, S.; Ullah, M.F.; Ahmad, A.; Sarkar, F.H.; Hadi, S.M. Redox cycling of endogenous copper by thymoquinone leads to ROS-mediated DNA breakage and consequent cell death: Putative anticancer mechanism of antioxidants. Cell Death Dis. 2013, 4, e660. [CrossRef]

103. Peng, L.; Liu, A.; Shen, Y.; Xu, H.Z.; Yang, S.Z.; Ying, X.Z.; Liao, W.; Liu, H.X.; Lin, Z.Q.; Chen, Q.Y.; et al. Antitumor and anti-angiogenesis effects of thymoquinone on osteosarcoma through the NF-kB pathway. Oncol. Rep. 2013, 29, 571-578. [CrossRef]

104. Salim, E.I. Cancer chemopreventive potential of volatile oil from black cumin seeds, Nigella sativa L., in a rat multi-organ carcinogenesis bioassay. Oncol. Lett. 2010, 1, 913-924. [CrossRef]

105. Abdelfadil, E.; Cheng, Y.H.; Bau, D.T.; Ting, W.J.; Chen, L.M.; Hsu, H.H.; Lin, Y.M.; Chen, R.J.; Tsai, F.J.; Tsai, C.H.; et al. Thymoquinone induces apoptosis in oral cancer cells through p38 $\beta$ inhibition. Am. J. Chin. Med. 2013, 41, 683-696. [CrossRef]

106. Chu, S.C.; Hsieh, Y.S.; Yu, C.C.; Lai, Y.Y.; Chen, P.N. Thymoquinone induces cell death in human squamous carcinoma cells via caspase activation-dependent apoptosis and LC3-II activation-dependent autophagy. PLoS ONE 2014, 9, e101579. [CrossRef]

107. Rajkamal, G.; Suresh, K.; Sugunadevi, G.; Vijayaanand, M.A.; Rajalingam, K. Evaluation of chemopreventive effects of Thymoquinone on cell surface glycoconjugates and cytokeratin expression during DMBA induced hamster buccal pouch carcinogenesis. BMB Rep. 2010, 43, 664-669. [CrossRef] [PubMed]

108. Subburayan, K.; Thayyullathil, F.; Pallichankandy, S.; Rahman, A.; Galadari, S. Par-4-dependent p53 up-regulation plays a critical role in thymoquinone-induced cellular senescence in human malignant glioma cells. Cancer Lett. 2018, 426, 80-97. [CrossRef]

109. Kotowski, U.; Heiduschka, G.; Kadletz, L.; Fahim, T.; Seemann, R.; Schmid, R.; Schneider, S.; Mitterbauer, A.; Thurnher, D.; Thurnher, D. Effect of thymoquinone on head and neck squamous cell carcinoma cells in vitro: Synergism with radiation. Oncol. Lett. 2017, 14, 1147-1151. [CrossRef] [PubMed]

110. Samuel, S.M.; Varghese, E.; Kubatka, P.; Triggle, C.R.; Büsselberg, D. Metformin: The answer to cancer in a flower? Current knowledge and future prospects of metformin as an anti-cancer agent in breast cancer . Biomolecules 2019, 9, 846. [CrossRef]

111. Baguley, B.C. Multiple drug resistance mechanisms in cancer. Mol. Biotechnol. 2010, 46, 308-316. [CrossRef] [PubMed]

112. Zahreddine, H.; Borden, K. Mechanisms and insights into drug resistance in cancer. Front. Pharmacol. 2013, 4, 28. [CrossRef]

113. Mu, G.G.; Zhang, L.L.; Li, H.Y.; Liao, Y.; Yu, H.G. Thymoquinone pretreatment overcomes the insensitivity and potentiates the antitumor effect of gemcitabine through abrogation of Notch1, PI3K/Akt/mTOR regulated signaling pathways in pancreatic cancer. Dig. Dis. Sci. 2015, 60, 1067-1080. [CrossRef] [PubMed]

114. Pandita, A.; Kumar, B.; Manvati, S.; Vaishnavi, S.; Singh, S.K.; Bamezai, R.N. Synergistic combination of gemcitabine and dietary molecule induces apoptosis in pancreatic cancer cells and down regulates PKM2 expression. PLoS ONE 2014, 9, e107154. [CrossRef] [PubMed]

115. Bashmail, H.A.; Alamoudi, A.A.; Noorwali, A.; Hegazy, G.A.; AJabnoor, G.; Choudhry, H.; Al-Abd, A.M. Thymoquinone synergizes gemcitabine anti-breast cancer activity via modulating its apoptotic and autophagic activities. Sci. Rep. 2018, 8, 11674. [CrossRef]

116. Şakalar, Ç.; İzgi, K.; İskender, B.; Sezen, S.; Aksu, H.; Çakır, M.; Kurt, B.; Turan, A.; Canatan, H. The combination of thymoquinone and paclitaxel shows anti-tumor activity through the interplay with apoptosis network in triple-negative breast cancer. Tumour Biol. 2016, 37, 4467-4477. [CrossRef]

117. Mohamed, A.M.; Refaat, B.A.; El-Shemi, A.G.; Kensara, O.A.; Ahmad, J.; Idris, S. Thymoquinone potentiates chemoprotective effect of Vitamin D3 against colon cancer: A pre-clinical finding. Am. J. Transl. Res. 2017, 9, 774. [PubMed]

118. Kensara, O.A.; El-Shemi, A.G.; Mohamed, A.M.; Refaat, B.; Idris, S.; Ahmad, J. Thymoquinone subdues tumor growth and potentiates the chemopreventive effect of 5-fluorouracil on the early stages of colorectal carcinogenesis in rats. Drug Des. Devel. Ther. 2016, 10, 2239.

119. Attoub, S.; Sperandio, O.; Raza, H.; Arafat, K.; Al-Salam, S.; Al Sultan, M.A.; Al Safi, M.; Takahashi, T.; Adem, A. Thymoquinone as an anticancer agent: Evidence from inhibition of cancer cells viability and invasion in vitro and tumor growth in vivo. Fundam. Clin. Pharmacol. 2013, 27, 557-569. [CrossRef] [PubMed] 
120. Effenberger-Neidnicht, K.; Schobert, R. Combinatorial effects of thymoquinone on the anti-cancer activity of doxorubicin. Cancer Chemother. Pharmacol. 2011, 67, 867-874. [CrossRef]

121. Soltani, A.; Pourgheysari, B.; Shirzad, H.; Sourani, Z. Antiproliferative and apoptosis-inducing activities of thymoquinone in lymphoblastic leukemia cell line. Indian J. Hematol. Blood Transfus. 2017, 33, 516-524. [CrossRef] [PubMed]

122. Rukoyatkina, N.; Butt, E.; Subramanian, H.; Nikolaev, V.O.; Mindukshev, I.; Walter, U.; Gambaryan, S.; Benz, P.M. Protein kinase A activation by the anti-cancer drugs ABT-737 and thymoquinone is caspase-3-dependent and correlates with platelet inhibition and apoptosis. Cell Death Dis. 2017, 8, e2898. [CrossRef] [PubMed]

123. Farooqui, Z.; Shahid, F.; Khan, A.A.; Khan, F. Oral administration of Nigella sativa oil and thymoquinone attenuates long term cisplatin treatment induced toxicity and oxidative damage in rat kidney. Biomed. Pharmacother. 2017, 96, 912-923. [CrossRef]

124. Nessa, M.U.; Beale, P.; Chan, C.; Yu, J.Q.; Huq, F. Synergism from combinations of cisplatin and oxaliplatin with quercetin and thymoquinone in human ovarian tumour models. Anticancer Res. 2011, 31, 3789-3797.

125. Liu, X.; Dong, J.; Cai, W.; Pan, Y.; Li, R.; Li, B. The effect of thymoquinone on apoptosis of SK-OV-3 ovarian cancer cell by regulation of Bcl-2 and Bax. Int. J. Gynecol. Cancer. 2017, 27, 1596-1601. [CrossRef] [PubMed]

126. Dirican, A.; Erten, C.; Atmaca, H.; Bozkurt, E.; Kucukzeybek, Y.; Varol, U.; Oktay Tarhan, M.; Karaca, B.; Uslu, R. Enhanced cytotoxicity and apoptosis by thymoquinone in combination with zoledronic acid in hormone-and drug-resistant prostate cancer cell lines. J. BUON 2014, 19, 1055-1061. [PubMed]

127. Alaufi, O.M.; Noorwali, A.; Zahran, F.; Al-Abd, A.M.; Al-Attas, S. Cytotoxicity of thymoquinone alone or in combination with cisplatin (CDDP) against oral squamous cell carcinoma in vitro. Sci. Rep. 2017, 7, 1313. [CrossRef] [PubMed]

128. Dogar, M.Z.; Adnan, H.; Akhtar, M.S.; Sheikh, M.A. Prelimiary assessment of efficacy of Nigella sativa seeds in acute lymphoblastic leukemia local children. Pharmacologyonline 2009, 2, 769-777.

129. Clinical and Immunohisochemical Evaluation of Chemopreventive Effect of Thymoquinone on Oral Potentially Malignant Lesions. Available online: https:/ / clinicaltrials.gov/ct2/show/NCT03208790 (accessed on 10 December 2020).

130. Al-Amri, A.A.; Bamoasa, A.O. Phase I safety and clinical activity of thymoquinone in patients with advanced refractory malignant disease. Shiraz E-Med. J. 2009, 10, 107-111.

131. Ansary, J.; Cianciosi, D. Natural antioxidants: Is the research going in the right direction? Med. J. Nutr. Metab. 2020, 13, 187-191. [CrossRef] 